$(200)$

$R 290$

no. $94-210 \mathrm{~W}$

METHODS OF ANALYSIS BY THE U.S. GEOLOGICAL SURVEY

NATIONAL WATER QUALITY LABORATORY--

DETERMINATION OF CHLORINATED PESTICIDES IN AQUATIC

TISSUE BY CAPILLARY-COLUMN GAS CHROMATOGRAPHY WITH

ELECTRON-CAPTURE DETECTION

By Thomas J. Leiker, James E. Madsen, Jeffrey R. Deacon, and William T. Foreman

U.S. GEOLOGICAL SURVEY

Open-File Report 94-710

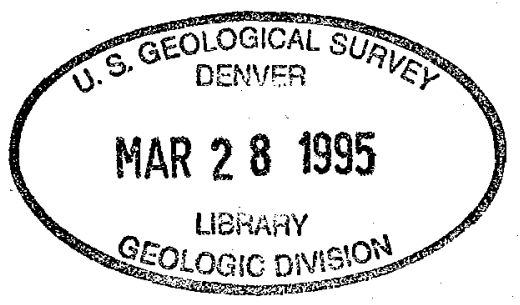

Denver, Colorado

1995

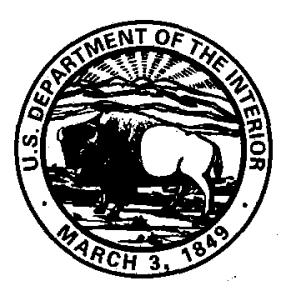




\section{U.S. DEPARTMENT OF THE INTERIOR BRUCE BABBITT, Secretary \\ U.S. GEOLOGICAL SURVEY \\ Gordon P. Eaton, Director}

The use of brand, firm, and trade names in this report is for identification purposes only and does not constitute endorsement by the U.S. Geological Survey.

For additional information write to:

U.S. Geological Survey

Chief, National Water Quality Laboratory

Box 25046, Mail Stop 407

Denver Federal Center

Denver, CO 80225
Copies of this report can be purchased from:

U.S. Geological Survey Open-File Reports Section/ESIC Box 25286, Mail Stop 517

Denver Federal Center

Denver, CO 80225 


\section{CONTENTS}

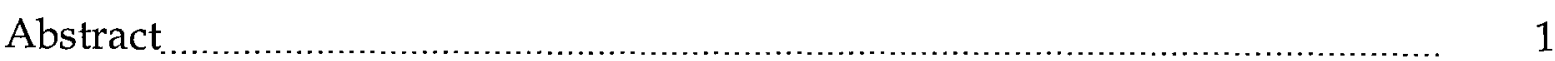

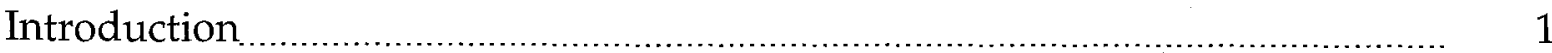

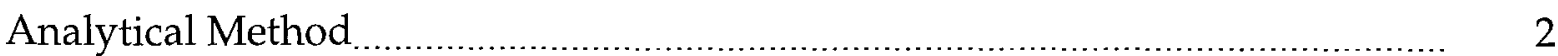

1. Scope and application ............................................................................. 2

2. Summary of method

3. Interferences.

4. Apparatus and equipment .................................................................... 4

5. Reagents and consumable materials ...................................................... 6

6. Sample collection and preparation .......................................................... 8

7. Analysis of sample extracts ............................................................ 12

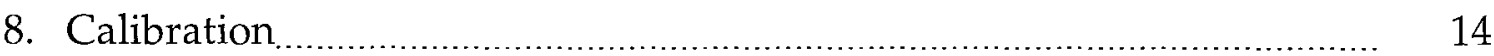

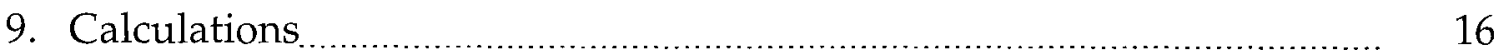

10. Reporting of results .............................................................................. 18

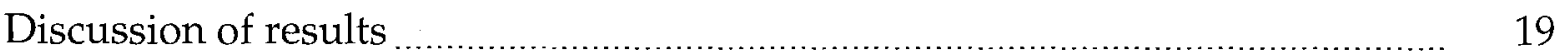

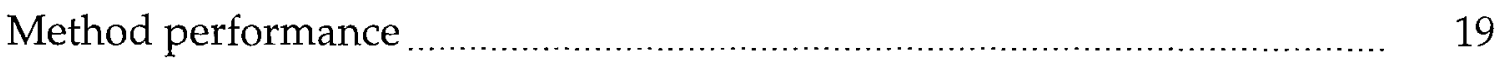

Method detection limits .......................................................................... 20

Quality assurance

Interpretation of laboratory quality-control data ......................................... 21

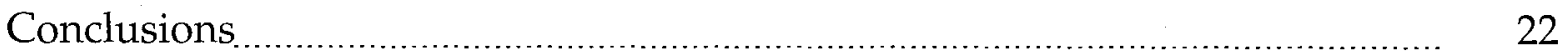

References cited

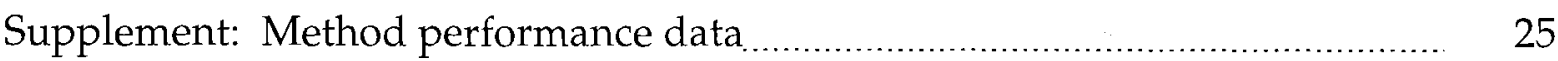

\section{TABLES}

Table 1. Compounds, codes, and Chemical Abstract Service registry numbers

2. Concentration data of nonspiked whole-body fish tissue used for 40-microgram-per-kilogram spike.

3. Percent recovery of 40-microgram-per-kilogram spike in homogenized whole-body fish tissue...

4. Concentration data of nonspiked whole-body fish tissue used for 30- and 100-microgram-per-kilogram spike. 
Table 5. Percent recovery of 30-microgram-per-kilogram spike in homogenized whole-body fish tissue.

6. Percent recovery of 100-microgram-per-kilogram spike in homogenized whole-body fish tissue.

7. Concentration data of nonspiked corbicula tissue used for 5- and 40-microgram-per-kilogram spike.

8. Percent recovery of 5-microgram-per-kilogram spike in homogenized corbicula tissue

9. Percent recovery of 40-microgram-per-kilogram spike in homogenized corbicula tissue

10. Percent recovery of 2.5-microgram-per-kilogram reagent spike.

11. Percent recovery of 40-microgram-per-kilogram reagent spike

12. Percent recovery from National Institute of Standards and

Technology Standard Reference Material 1588 cod liver oil

13a. Results of U.S. Fish and Wildlife round-robin sample 2

13b. Results of U.S. Fish and Wildlife round-robin sample 12

14. Results of U.S. Environmental Protection Agency quality-control samples.

15. Method detection limits determined with reagent spike

16. Method detection limits determined with homogenized fish tissue... 


\section{CONVERSION FACTORS, ABBREVIATED WATER-QUALITY UNITS, AND ADDITIONAL ABBREVIATIONS AND SYMBOLS}

\begin{tabular}{lcl}
\hline \multicolumn{1}{c}{ Multiply } & By & To obtain \\
\hline centimeter $(\mathrm{cm})$ & $3.94 \times 10^{-1}$ & inch \\
gram $(\mathrm{g})$ & $3.52 \times 10^{-2}$ & ounce \\
liter $(\mathrm{L})$ & 0.265 & gallon \\
meter $(\mathrm{m})$ & 3.28 & foot \\
microliter $(\mu \mathrm{L})$ & $2.64 \times 10^{-7}$ & gallon \\
milligram $(\mathrm{mg})$ & $3.53 \times 10^{-5}$ & ounce \\
milliliter $(\mathrm{mL})$ & $2.64 \times 10^{-4}$ & gallon \\
millimeter $(\mathrm{mm})$ & $3.94 \times 10^{-2}$ & inch \\
nanometer $(\mathrm{nm})$ & $3.93 \times 10^{-8}$ & inch \\
\hline
\end{tabular}

Degree Celsius $\left({ }^{\circ} \mathrm{C}\right)$ may be converted to degree Fahrenheit $\left({ }^{\circ} \mathrm{F}\right)$ by using the following equation:

$$
\mathrm{oF}=9 / 5\left({ }^{\circ} \mathrm{C}\right)+32 .
$$

Abbreviated water-quality units used in this report are as follows:

${ }^{\circ} \mathrm{C} / \mathrm{min}$ degree Celsius per minute

$\mu \mathrm{g} / \mathrm{kg} \quad$ microgram per kilogram

$\mathrm{mg} / \mathrm{mL} \quad$ milligram per milliliter

$\mathrm{mL} / \mathrm{min}$ milliliter per minute $\mathrm{ng} / \mu \mathrm{L}$ nanogram per microliter

$\mathrm{pg} / \mu \mathrm{L}$ picogram per microliter

$\mathrm{lb} / \mathrm{in}^{2}$ pounds per square inch

Other abbreviations used in this report:

CAS Chemical Abstract Service

$\mathrm{CCV}$ continuing calibration verification

GC gas chromatography

GC/ECD gas chromatography/electron capture detection

GPC gel permeation chromatography

id inside diameter

K-D Kuderna-Danish concentrator

MDL method detection limit

NAWQA National Water-Quality Assessment program

NIST National Institute of Standards and Technology

NWQL National Water Quality Laboratory

PCB polychlorinated biphenyls

PEM performance evaluation mix

QC quality control

RSD relative standard deviation

SOP standard operating procedure

SRM Standard Reference Material

USEPA U.S. Environmental Protection Agency

USFWS U.S. Fish and Wildlife Service 


\title{
METHODS OF ANALYSIS BY THE U.S. GEOLOGICAL SURVEY NATIONAL WATER QUALITY LABORATORY-- DETERMINATION OF CHLORINATED PESTICIDES IN AQUATIC TISSUE BY CAPILLARY-COLUMN GAS CHROMATOGRAPHY WITH ELECTRON-CAPTURE DETECTION
}

By Thomas J. Leiker, James E. Madsen, Jeffrey R. Deacon, and William T. Foreman

\begin{abstract}
A method for the determination of chlorinated organic compounds in aquatic tissue by dual capillary-column gas chromatography with electron-capture detection is described. Whole-body-fish or corbicula tissue is homogenized, Soxhlet extracted, lipid removed by gel permeation chromatography, and fractionated using alumina / silica adsorption chromatography. The extracts are analyzed by dissimilar capillarycolumn gas chromatography with electron-capture detection. The method reporting limits are 5 micrograms per kilogram $(\mu \mathrm{g} / \mathrm{kg})$ for chlorinated compounds, $50 \mu \mathrm{g} / \mathrm{kg}$ for polychlorinated biphenyls, and $200 \mu \mathrm{g} / \mathrm{kg}$ for toxaphene.
\end{abstract}

\section{INTRODUCTION}

Historically the water quality of ground, surface, or impounded water is often established by determining the concentration of organic compounds present in a 1- $\mathrm{L}$ sample. Because of surface-water variability in time and ground-water availability in space, an analysis based on a 1-L sample might not produce a true water-quality picture. Hydrophobic organic compounds such as chlorinated pesticides, PCBs, and other chlorinated organic compounds often are present in the water column at concentrations less than the detection limits of conventional analytical techniques. These sparingly soluble compounds usually exhibit high octanol to water partition coefficients (Log $\mathrm{K}_{\mathrm{OW}}>4$ ) and are selectively partitioned from the water column into organic material associated with bed and suspended sediment and into the lipid tissue of stream biota.

The water quality of a riverine system is based on, but not limited to, atmospheric deposition, ground water, agricultural runoff, municipal and industrial discharges, and barge transportation of chemical, food, and agricultural products along major rivers. Runoff from forest, cattle, pork, and poultry industries also has an impact on water quality. Various studies have determined contaminant levels in sediment, water, and aquatic tissue as an index of water quality and agricultural run-off patterns (Barthel and others, 1969; Laska and others, 1976; Sabourin and others, 1984; Winger and Andreasen, 1985; Leiker and others, 1991). Other studies 
have demonstrated that organic contaminants with high Log $\mathrm{K}_{\mathrm{Ow}}$, which are present in the water column at nanogram-per-liter levels, will bioconcentrate within the lipid tissues of aquatic biota (Jaffe and others, 1985; Oliver and Niimi, 1985; Pereira and others, 1988; Swackhamer and Hites, 1988; Leiker and others, 1991). Because of these studies, measuring the pesticide content in tissue samples might provide data to determine long-term water-quality trends, identify sources of contamination in rivers and streams, monitor changes in land-use patterns, and indicate when new hydrophobic pesticides are being used.

This report describes a method for determining chlorinated pesticides and industrial chemicals in whole-body-fish and corbicula tissue. The method was developed by the U.S. Geological Survey for its National Water-Quality Assessment (NAWQA) program for use at the National Water Quality Laboratory (NWQL). Other methods of the U.S. Geological Survey for determination of organic compounds are described by Wershaw and others (1987). The method was implemented at the NWQL in November 1992.

This report provides detailed information regarding sample preparation and analysis, interferences, calculations, accuracy and precision of the method validation, explanation of quality-control data, round-robin results for further validation, and method detection limits for 28 chlorinated compounds.

The authors acknowledge the technical support of Brooke Connor, Dennis Markovchick, Tammy Thompson, Gene Slocum, and Anthony Sofia. Additional thanks are accorded to Stuart McKenzie and Stephen Porter, who supplied tissue samples for the method's development and validation; Wilfred Pereira, Charles Demas, and Greg Foster provided helpful discussions.

\author{
ANALYTICAL METHOD \\ Organic Compounds and Parameter Codes: \\ Chlorinated pesticides, recoverable from aquatic tissue, \\ capillary-column gas chromatography, electron-capture detection, \\ O-9125-94 (see table 1)
}

\title{
1. Scope and application
}

1.1 This method is suitable for the determination of selected organochlorinecontaining pesticides and industrial chemicals in whole-body fish and corbicula tissue at concentrations of $5 \mu \mathrm{g} / \mathrm{kg}$ for chlorinated pesticides, $50 \mu \mathrm{g} / \mathrm{kg}$ for PCBs, and $200 \mu \mathrm{g} / \mathrm{kg}$ for toxaphene. The method is applicable for those hydrophobic compounds that exhibit $\log \mathrm{K}_{\mathrm{OW}}>4$. The method is used to determine the concentration of 28 chlorinated organic compounds listed in table 1 . These 28 compounds were selected for analysis to fulfill the requirements of the NAWQA 
program. In addition, 3,5-dichlorobiphenyl and alpha-HCH- $\mathrm{d}_{6}$ were used as surrogates for quality control (table 1). Recovery from a matrix spike might not indicate the true concentration of a compound originally present in the sample because of mechanisms that are only active in a living organism that might irreversibly bind chlorinated pesticides to the tissues.

Table 1. Compounds, codes, and Chemical Abstract Service registry numbers

[WATSTORE, Water Data Storage and Retrieval System; NWQL, National Water Quality Laboratory; CAS, Chemical Abstract Service; --, no code assigned]

\begin{tabular}{lccr}
\hline \multicolumn{1}{c}{ Compound } & $\begin{array}{c}\text { WATSTORE } \\
\text { code }\end{array}$ & $\begin{array}{c}\text { NWQL } \\
\text { code }\end{array}$ & $\begin{array}{c}\text { CAS } \\
\text { registry number }\end{array}$ \\
\hline Aldrin & 49353 & 7030 & $309-00-2$ \\
cis-Chlordane & 49380 & 7001 & $5103-71-9$ \\
trans-Chlordane & 49379 & 7002 & $5103-74-2$ \\
DCPA (dacthal) & 49378 & 7003 & $1861-32-1$ \\
o,p'-DDD & 49374 & 7007 & $53-19-0$ \\
p,p'-DDD & 49375 & 7006 & $72-54-8$ \\
o,p'-DDE & 49373 & 7008 & $3424-82-6$ \\
p, $p^{\prime}$-DDE & 49372 & 7009 & $72-55-9$ \\
o,p'-DDT & 49377 & 7004 & $789-02-6$ \\
p,p'-DDT & 49376 & 7005 & $50-29-3$ \\
Dieldrin & 49371 & 7010 & $60-57-1$ \\
Endrin & 49370 & 7011 & $72-20-8$ \\
alpha-HCH & 49366 & 7016 & $319-84-6$ \\
beta-HCH & 49365 & 7017 & $319-85-7$ \\
delta-HCH & 49364 & 7018 & $319-86-8$ \\
gamma-HCH (lindane) & 49363 & 7019 & $58-89-9$ \\
Heptachlor & 49369 & 7012 & $76-44-8$ \\
Heptachlor epoxide & 49368 & 7013 & $1024-57-3$ \\
Hexachlorobenzene & 49367 & 7014 & $118-74-1$ \\
o,p'-Methoxychlor & 49362 & 7020 & $30667-99-3$ \\
p,p'-Methoxychlor & 49361 & 7021 & $72-43-5$ \\
Mirex & 49360 & 7022 & $2385-85-5$ \\
cis-Nonachlor & 49359 & 7023 & $5103-73-1$ \\
trans-Nonachlor & 49358 & 7024 & $39765-80-5$ \\
Oxychlordane & 49357 & 7025 & $27304-13-8$ \\
Pentachloroanisole & 49356 & 7027 & $1825-21-4$ \\
Total PCB & 49354 & 7029 & -- \\
Toxaphene & 49355 & 7028 & $8001-35-2$ \\
3,5-Dichlorobiphenyl (surrogate) & 49264 & 7035 & $34883-41-5$ \\
alpha-HCH-d6 (surrogate) & 49261 & 7034 & -- \\
\hline
\end{tabular}


1.2 Method performance was validated by analyzing seven replicates at low and high concentrations of all 28 selected compounds in the following sample matrices: whole-body-fish tissue, corbicula tissue, and reagent blank consisting of sodium sulfate. Further validation involved analysis of Standard Reference Material (SRM-1588 cod liver oil) from the National Institute of Standards and Technology (NIST), and U.S. Environmental Protection Agency (USEPA) Quality Control Fish Tissue. U.S. Fish and Wildlife Service round-robin samples, from its contract laboratories program, were also analyzed.

\section{Summary of method}

2.1 Whole-body-fish or corbicula tissue is homogenized into a single composite.

2.2 A 10-g sample aliquot of homogenized tissue is thoroughly mixed with $100 \mathrm{~g}$ of granular anhydrous sodium sulfate and Soxhlet extracted overnight with methylene chloride.

2.3 After extraction, the extract is concentrated to a volume of $5.0 \mathrm{~mL}$. A $1-\mathrm{mL}$ aliquot is removed for percentage lipid determination. A 2-mL aliquot of the extract is injected into a gel permeation chromatograph (GPC) to separate the lipid material and other interferences from the method compounds.

2.4 After the compounds have been collected from the GPC, the extract is solvent exchanged into hexane, separated into two fractions on a column packed from top to bottom with $1 \mathrm{~cm}$ of sodium sulfate, $5 \mathrm{~g}$ of 8.5 percent water-deactivated alumina, $3 \mathrm{~g}$ of 2 percent water-deactivated silica, and $0.5 \mathrm{~cm}$ of sodium sulfate.

2.4.1 The first fraction contains the PCBs, DDE, and other nonpolar organics.

2.4.2 The second fraction contains toxaphene, chlordane components, DDT, DDD, and other more polar organic compounds.

2.5 Each fraction is concentrated to a volume of $1 \mathrm{~mL}$ and analyzed by dual capillary-column gas chromatography with electron-capture detection.

\section{Interferences}

Compounds recovered from a sample matrix, which have chemical and physical properties that are similar to but are not chromatographically resolved from the compounds of interest, can interfere.

\section{Apparatus and equipment}

\subsection{Blender, Waring.}




\subsection{Soxhlet extractors.}

4.2.1 Round-bottom flasks, 500-mL.

\subsubsection{Condensers.}

4.3 Soxhlet thimble, glass-fiber, precleaned overnight at $450^{\circ} \mathrm{C}$.

4.4 Boiling chips (large).

4.5 Kuderna-Danish (K-D) apparatus.

4.5.1 Flasks, 500-mL K-D.

4.5.2 Three-ball Snyder columns.

4.5.3 Receivers, 10-, 25-, and 50-mL K-D.

4.6 GPC autosampler vials, $4-\mathrm{mL}$.

4.7 Miscellaneous items.

4.7.1 Evaporative concentrators.

4.7.2 Metal spatulas.

4.8 Analytical balance.

4.8.1 Balance capable of accurately weighing up to $1,200 \mathrm{~g} \pm 0.1 \mathrm{~g}$.

4.8.2 Analytical balance capable of accurately weighing $200 \mathrm{~g} \pm 0.1 \mathrm{mg}$.

4.9 Gas chromatograph equipped with the following items:

4.9.1 Capillary column: two $25-\mathrm{m} \times 0.25$ - $\mathrm{mm}$ inside diameter (id) fusedsilica-capillary columns--one is coated with 5 percent diphenyl and 95 percent dimethyl polysiloxane (Restek Rtx-5), and the other is coated with 14 percent cyanopropyl and 86 percent dimethyl polysiloxane (Restek Rtx-1701) or equivalent.

4.9.2 Autosampler capable of variable syringe draw-up rate.

4.9.3 Detectors, two nickel-63 electron-capture.

4.9.4 Data station capable of producing chromatograms and quantitative reports.

4.9.5 Temperature-controlled injection ports, detectors, and gas chromatography (GC) oven capable of multitemperature program ramps. 
4.10 Gel permeation chromatograph equipped with the following items:

4.10.1 Solvent delivery system with variable pumping rates.

4.10.2 Autosampler with sample storage carousel and variable syringe draw rate.

4.10.3 Gel permeation columns: two Waters Envirogel GPC Prep Columns $19 \times 150 \mathrm{~mm}$ and $19 \times 300 \mathrm{~mm}$ or equivalent.

4.10.4 Ultraviolet detector set at $254 \mathrm{~nm}$.

4.10.5 Fraction collector.

4.10.6 Data station or integrator capable of producing chromatograms and quantitative reports.

4.11 Mason jars, pint- and quart-size, precleaned overnight at $450^{\circ} \mathrm{C}$.

\section{Reagents and consumable materials}

5.1 Helium gas chromatography (GC) carrier gas (grade 5).

5.2 Nitrogen GC makeup gas (grade 5).

5.3 Nitrogen, ultrapure gas for evaporation.

5.4 Scrubbers to remove oxygen and impurities from carrier gas.

5.5 Solvents: Acetone, hexane, isooctane, methylene chloride, methanol, toluene, cyclohexane; B\&J brand, ultrapure pesticide quality or equivalent.

5.6 Syringes, 10-, 25-, 50-, and 100- $\mu \mathrm{L}$.

5.7 Class A pipet, 2-mL.

5.8 Disposable 127- and 229-mm Pasteur pipets, precleaned by baking at $450^{\circ} \mathrm{C}$ overnight.

5.9 Sodium sulfate, granular, preclean by baking at $450^{\circ} \mathrm{C}$ overnight.

5.10 Obtain standards for calibration curves, surrogate and internal standards, retention-time markers, continuing calibration verification $(\mathrm{CCV})$ and performance evaluation mix (PEM) standards, and reagent spike solutions at a certified concentration or prepare from pure primary standards. 
5.10.1 Calibration standards include all method compounds at concentrations of 5, 10, 20, 50, 100, and 200 picograms per microliter (pg/ $\mu \mathrm{L})$. Prepare the standards in hexane or cyclohexane. The PCB calibration standard contains a 1:1:1 mixture of Aroclor 1242,1254, and 1260 at $200 \mathrm{pg} / \mu \mathrm{L}$ each in hexane or cyclohexane. The toxaphene calibration standard is $1,200 \mathrm{pg} / \mu \mathrm{L}$.

5.10.2 Add surrogate standards consisting of 3,5-dichlorobiphenyl and alpha- $\mathrm{HCH}_{-} \mathrm{d}_{6}$, in hexane, at a concentration of $2.5 \mathrm{ng} / \mu \mathrm{L}$ to each sample prior to Soxhlet extraction. Use a $100-\mu \mathrm{L}$ syringe to fortify the sample with $100 \mu \mathrm{L}$ of surrogate spiking solution. Alternate surrogate compounds may be used after demonstrating adequate performance. This standard provides sample processing information on every environmental sample that is analyzed.

5.10.3 Add retention-time-marker solution of tetrachloro- $m$-xylene and decachlorobiphenyl to the sample at the time the sample extract is transferred to a vial and sealed. Prepare the retention-time-marker solution at $10 \mathrm{ng} / \mu \mathrm{L}$ in hexane, and fortify the sample with $10 \mu \mathrm{L}$ of this solution. Use this retention-time marker to monitor and correct for small drift in GC retention time of method compounds. Also use it for internal standard quantification when required. The conditions for internal standard quantification are dependent on the stability of the instrument and the sample matrix. Use internal standard quantification only when external quantification fails because of matrix effects or instrumental instability (McNair and Bonelli, 1969; U.S. Environmental Protection Agency, 1990).

5.10.4 The CCV standards include all method compounds prepared at 50 $\mathrm{pg} / \mu \mathrm{L}$. Analyze this standard after every fifth environmental sample to monitor and ensure the validity of the calibration curve throughout the GC analysis for all samples and compounds.

5.10.5 The PEM standards include alpha-, beta-, and gamma-HCH $(10 \mathrm{pg} / \mu \mathrm{L}), p, p^{\prime}$-DDT $(100 \mathrm{pg} / \mu \mathrm{L})$, endrin $(50 \mathrm{pg} / \mu \mathrm{L})$, and $p, p^{\prime}$-methoxychlor $(250 \mathrm{pg} / \mu \mathrm{L})$. Use these standards to monitor the resolution of the chromatographic separations, and chromatographic and injection port degradation of method compounds, thereby providing data to indicate when to perform maintenance on the chromatographic system.

5.10.6 Prepare a 1.25-ng/ $\mu \mathrm{L}$ reagent spike solution, in hexane, consisting of all single-component method compounds, and spike $100 \mu \mathrm{L}$ directly into the sodium sulfate prior to Soxhlet extraction.

5.10.7 Prepare a GPC system performance verification standard, in methylene chloride, to monitor the performance of the GPC. Use this standard to monitor the retention times and resolution of the GPC columns that separate the method compounds from the coextracted lipid material. The standard consists of corn oil, $63,000 \mathrm{mg} / \mathrm{L}$; bis-2-ethyl-hexylphthalate, 2,000 mg/L; perylene, $45 \mathrm{mg} / \mathrm{L}$; and sulfur, $220 \mathrm{mg} / \mathrm{L}$. 
5.11 Prepare working standards from pure primary materials as follows: Using an analytical balance capable of weighing to $\pm 0.1 \mathrm{mg}$, weigh 5 to $10 \mathrm{mg}$ of primary standard directly into a 5- or 10-mL volumetric flask. Dilute to volume with hexane or cyclohexane. Verify that all of the solid material has gone into solution. After preparation, transfer the standard to an appropriate vial labeled with the date that the standard was prepared, concentration, solvent, purity of the primary . material, and a mark on the side of the vial to record the volume at time of preparation. Seal the vial with a Teflon-lined screw cap and store in a freezer for a maximum of 6 months. Date and re-mark the level of solvent every time an aliquot is withdrawn.

5.12 Prepare or obtain working standard solutions at concentrations from 1 to $2 \mathrm{mg} / \mathrm{mL}$. Prepare all subsequent dilutions with $10-, 25-, 50-$, or $100-\mu \mathrm{L}$ syringes. Transfer the aliquot required to prepare a standard at a given concentration directly into a volumetric flask and dilute to volume with hexane or cyclohexane. Transfer the solution to a Teflon-lined screw-cap vial and store for a maximum of 3 months.

5.13 After preparation, check all standard stock solutions against existing standards. All standard stock solutions must fall within 20 percent of existing standards. Under no circumstances are these solutions to be validated separately or on different days. Never store the standard stock solutions in volumetric flasks or at ambient temperature overnight, regardless of the storage container.

\section{Sample collection and preparation}

6.1 Collect fish and corbicula samples according to guidelines set forth by Crawford and Luoma (1993). Briefly, collect fish samples by electroshocking, wrap in aluminum foil, freeze, and ship frozen to NWQL. Collect corbicula samples, depurate for 22 hours, wrap in aluminum foil, and ship frozen to NWQL.

6.2 Preparation and homogenization of whole-body fish tissue.

6.2.1 Allow samples, wrapped in aluminum foil, to thaw overnight at ambient temperature.

6.2.2 After thawing, composite and thoroughly homogenize all fish (typically 5 to 10) from a specific sampling site by five repetitive processings through a meat grinder. Place about $300 \mathrm{~g}$ of homogenized tissue in a clean jar and store the homogenized tissue in a freezer. Discard the remaining bulk quantity of tissue. Observe all safety requirements established by the manufacturer of the meat grinder.

6.2.3 Wash all components of the meat grinder with soap and hot water, and rinse with organic-free distilled water, methanol or acetone, and methylene chloride between samples. 


\subsection{Preparation and homogenization of corbicula.}

6.3.1 After thawing, remove the corbicula tissue from the shell using precleaned spatulas that have been baked at $450^{\circ} \mathrm{C}$ overnight. Open the shell with the spatula and scrape the tissue from the shell directly into a clean mason jar. Composite and homogenize all tissue from a specific sampling site. Wear gloves to prevent transfer of finger oil to the sample.

6.3.2 Homogenize the corbicula tissue with a stainless steel blender. Place up to $300 \mathrm{~g}$ of homogenized tissue in a clean jar and store the homogenized tissue in a freezer. Clean the components of the blender that come in contact with the sample in the same manner as the meat grinder (see section 6.2.3).

6.4 After homogenizing composite samples, weigh about $10 \mathrm{~g}$ of homogenized tissue directly into a preweighed pint-size mason jar that contains $100 \mathrm{~g}$ of granular anhydrous sodium sulfate. Weigh the jar to the nearest $0.1 \mathrm{~g}$ and record the actual weight of sample that is placed in the mason jar. Refreeze the sample sodium sulfate mixture and store frozen until the sample is prepared for extraction.

6.5 Prior to extraction, while the sample is still frozen in the mason jar, use a blender to thoroughly homogenize the sample sodium sulfate mixture to a freeflowing powder. If any of the sample sodium sulfate mixture is retained on the blender blades, scrape the material or rinse the blades into the mason jar containing the sample sodium sulfate mixture.

6.6 After homogenization, quantitatively transfer the sample sodium sulfate mixture to a glass-fiber Soxhlet thimble that was baked at $450^{\circ} \mathrm{C}$ overnight. Add 100 $\mu \mathrm{L}$ of a $2.5-\mathrm{ng} / \mu \mathrm{L}$ surrogate standard solution to the sample prior to extraction. Rinse the mason jar three times with $20 \mathrm{~mL}$ of methylene chloride. Add the rinses to the Soxhlet apparatus, and extract the sample for a minimum of 8 hours with $250 \mathrm{~mL}$ of methylene chloride. The solvent should cycle through the Soxhlet apparatus about every 15 or 20 minutes.

6.7 After extraction, add $10 \mathrm{~g}$ of granular anhydrous sodium sulfate to the round-bottom flask that contains the extract to remove any water that may be present. Allow the extract and granular anhydrous sodium sulfate to set for 1 hour. Then decant the extract into an assembled K-D unit (500-mL flask with three-ball Synder column). Rinse the sides of the round-bottom flask containing the sample extract and granular anhydrous sodium sulfate three times with $20 \mathrm{~mL}$ of methylene chloride, and add the rinses to the K-D unit. Concentrate the extract and rinses by K-D to a volume of $5 \mathrm{~mL}$. Filter the extract through a disposable 127-mm Pasteur pipet that contains $25 \mathrm{~mm}$ of granular anhydrous sodium sulfate, collect the filtered extract in a 10-mL K-D receiver, rinse the sodium sulfate column with two column volumes of methylene chloride, and combine the rinses with the sample extract. Concentrate the extract to $5.0 \mathrm{~mL}$ under a gentle stream of nitrogen at ambient temperature. 
6.8 Transfer a 1-mL aliquot of the extract to a tared $15-\mathrm{mL}$ culture tube for percentage lipid determination.

6.8.1 Evaporate the $1 \mathrm{~mL}$ of extract to dryness at ambient temperature and under a gentle stream of nitrogen, or use a turbovap.

6.8.2 After removing the solvent, weigh the culture tube until a constant weight is achieved and record the constant weight.

6.8.3 Calculate the percentage of lipid using the following formula:

$$
\text { Percentage lipid }=\frac{\left(W_{t s}-W_{t}\right)}{1 \mathrm{~mL}} \times \frac{5 \mathrm{~mL}}{S_{w}} \times 100
$$

where $W_{t s}=W_{t}$ plus the weight of lipid contained in $1 \mathrm{~mL}$ of extract after solvent has been removed;

$W_{t}=$ culture tube tare weight; and

$S_{w}=$ weight of sample extracted (use weight recorded in section 6.4).

6.9 Transfer the remaining $4 \mathrm{~mL}$ of extract $\left(S_{v}\right)$ to a tared 4-mL GPC vial, seal with the Teflon-lined screw cap, and pressurize with nitrogen.

6.9.1 Pressurize each GPC vial with $30 \mathrm{lb} / \mathrm{in}^{2}$ of nitrogen for 30 seconds by piercing the septum with the pressurization needle. Withdraw the syringe needle from the septum. Rinse the needle by bubbling into a few milliliters of methylene chloride between each sample. Weigh and record the weight of the filled vial $\left(V_{w}{ }^{\prime}\right)$ to the nearest $1 \mathrm{mg}$. (CAUTION: Do not place the needle into the extract.)

6.10 Place the sample vial into the carousel of the GPC autosampler. Inject a 2-mL aliquot of the extract into the GPC for separation of lipid material from the method compounds. Collect the GPC fraction containing the method compounds into a 50-mL K-D receiver tube. For details regarding the setup, operation, and compound collection times, refer to SOP OT0028.0 (unpublished SOPs are available from the NWQL). After the sample has been injected into the GPC, reweigh the vial with the Teflon-lined screw cap and record its weight to the nearest $0.1 \mathrm{mg}\left(V_{w}{ }^{\prime}\right)$ Calculate the equivalent mass of tissue extract injected into the GPC, using the following formula:

$$
S_{v}=\left(V_{w}-V_{w}\right) / 1.32
$$

where $S_{V}=$ the volume of extract, in milliliters, that is injected into the GPC;

$V_{w}=$ the weight of the vial plus sample prior to GPC;

$V_{w}{ }^{\prime}=$ the weight of the vial minus the sample that has been injected into the GPC; and

1.32 = density of methylene chloride, in grams per milliliter. 
Then calculate the equivalent mass of tissue extract injected into the GPC, using

$$
S_{a}=\left(S_{w} / 5 \mathrm{~mL}\right) * S_{v}
$$

where $S_{a}=$ the equivalent mass of tissue extract injected into the GPC; and

$S_{w}=$ weight of sample extracted in grams (use weight recorded in section 6.4).

Use this value to calculate the final concentrations of compound, in micrograms per kilogram, in the sample.

6.10.1 Use a Waters liquid chromatographic system to carry out the gel permeation chromatography. Lipid material is separated from the compounds of interest using two Waters Envirogel GPC Prep Columns. The first column is a guard column $19 \times 150 \mathrm{~mm}$. The second column is $19 \times 300 \mathrm{~mm}$. The mobile phase is methylene chloride, and the flow rate of the mobile phase is $4.5 \mathrm{~mL} / \mathrm{min}$.

6.10.2 The separation of coextracted lipid material from method compounds is monitored by an ultraviolet detector set at a wavelength of $254 \mathrm{~nm}$. If the retention times shift by more than 2 minutes, as determined by the GPC evaluation standard, terminate the sequence and take corrective action.

6.10.3 The following is a typical GPC sequence for standards, environmental samples, and quality-control (QC) samples: GPC evaluation standard, seven environmental samples, duplicate environmental sample, four environmental samples, SRM, reagent spike, reagent blank, and GPC evaluation standard.

6.11 Collect the compounds of interest in a $50-\mathrm{mL}$ receiver. After collection, attach a three-ball Snyder column to the $50-\mathrm{mL}$ receiver, add boiling chips, place the unit on a steam bath, and concentrate to a volume of $5 \mathrm{~mL}$. Remove the unit from the steambath, and allow to cool. Then add $25 \mathrm{~mL}$ of hexane and new boiling chips to the extract, and concentrate the extract to a volume of $5 \mathrm{~mL}$ on a steam bath. Further concentrate the extract to $1 \mathrm{~mL}$ under a gentle stream of nitrogen at ambient temperature. At this point all methylene chloride has been removed from the extract. If the methylene chloride is not removed, the separations in the next step will fail.

6.12 Separate the extract into two fractions using a $265-\mathrm{mm}$ by $12.5-\mathrm{mm}$ id chromatographic column equipped with a $75-\mathrm{mL}$ reservoir and porous frit. Dry pack the column from top to bottom with $1 \mathrm{~cm}$ of granular sodium sulfate, $5 \mathrm{~g}$ of 8.5 percent water-deactivated neutral alumina (initially activated at $135^{\circ} \mathrm{C}$ ), $3 \mathrm{~g}$ of 2 percent water-deactivated silica (initially activated at $135^{\circ} \mathrm{C}$ ), and $0.5 \mathrm{~cm}$ of granular sodium sulfate.

6.12.1 Prerinse the column with $50 \mathrm{~mL}$ of hexane. 
6.12.2 As the hexane rinse sinks into the top of the sodium sulfate, transfer the $1 \mathrm{~mL}$ of sample extract to the top of the sodium sulfate, taking care not to disturb the alumina silica bed, and elute with $30 \mathrm{~mL}$ of hexane (discard the first $5 \mathrm{~mL}$ of hexane), collecting this first eluant in a $25-\mathrm{mL}$ K-D receiver. This first fraction contains PCBs, $p, p^{\prime}-\mathrm{DDE}, \mathrm{HCB}$, and other nonpolar organic compounds. Just prior to adding $25 \mathrm{~mL}$ of 50 percent (volume:volume) acetone in hexane, place a fresh 25-mL K-D receiver into position to collect the second fraction. The second fraction contains toxaphene, chlordane components, DDT, DDD, $\mathrm{HCH}$ isomers, and other more polar organic compounds.

6.13 Concentrate each fraction to a volume of $1 \mathrm{~mL}$, label a 2-mL GC autosampler vial, transfer extract to the GC autosampler vial, add exactly $10 \mu \mathrm{L}$ of a $10-\mathrm{ng} / \mu \mathrm{L}$ retention-time-marker solution to the extract, cap with a Teflon-lined cap, and store in a freezer until the sample is analyzed.

\section{Analysis of sample extracts}

7.1 Analyze sample extracts by dual capillary-column gas chromatography with electron-capture detection. Make chromatographic separations with two dissimilar $30-\mathrm{m}$ by $0.25-\mathrm{mm}$ id capillary columns, one of which is coated with 5 percent diphenyl and 95 percent dimethyl polysiloxane, and the other is coated with 14 percent cyanopropylphenyl and 86 percent dimethyl polysiloxane.

7.2 Hold the GC oven temperature at $50^{\circ} \mathrm{C}$ for 1 minute and program at $15^{\circ} \mathrm{C} / \mathrm{min}$ to $140^{\circ} \mathrm{C}$, then program at $1{ }^{\circ} \mathrm{C} / \mathrm{min}$ to a temperature of $220^{\circ} \mathrm{C}$; next program the oven at $4^{\circ} \mathrm{C} / \mathrm{min}$ to a temperature of $280^{\circ} \mathrm{C}$ and hold at the upper temperature for 20 minutes. Hold the injection port temperature at $220^{\circ} \mathrm{C}$ and the detector temperature at a minimum of $300^{\circ} \mathrm{C}$. Other GC temperature programs are permissible as long as acceptable chromatographic separations, compound identifications, and quantitations are maintained.

7.3 Place the vials containing the extracts into the autosampler tray.

7.4 Set the autosampler to rinse syringe five times with clean solvent prior to the $2-\mu \mathrm{L}$ injection of sample extract.

7.5 Base the compound identifications on comparison of GC retention times with authentic standards. Base the quantitation on a six-point calibration curve for all chlorinated pesticides and a single-point calibration for PCBs and toxaphene. Produce the six-point calibration curve for the chlorinated pesticides at the beginning of the analysis for each set of environmental samples and associated quality-control samples. The calibration range for all single-component compounds is $5,10,20,50,100$, and $200 \mathrm{pg} / \mu \mathrm{L}$. The calibration curve is acceptable if the correlation coefficient is greater than 0.995 . The recommended calibration standard for PCB is $600 \mathrm{pg} / \mu \mathrm{L}$ (a 1:1:1 mixture of Aroclor 1242, 1254, and 1260 at $200 \mathrm{pg} / \mu \mathrm{L}$ 
for each Aroclor type), and toxaphene is $800 \mathrm{pg} / \mu \mathrm{L}$. Depending on the concentration of $\mathrm{PCB}$ and toxaphene in the sample extract, the analyst has the discretion to alter the amount of standard to be more representative of the concentrations in the actual sample extract.

7.6 As part of the instrumental quality-control program, analyze continuing calibration verification (CCV) standards at $50 \mathrm{pg} / \mu \mathrm{L}$ and performance evaluation mix (PEM, section 5.10.5) standards consisting of alpha-, beta-, and gamma-HCH, p, p'$\mathrm{DDT}$, and $p, p^{\prime}$-methoxychlor after every fifth environmental sample. Analyze the CCV standard to ensure that the calibration has not drifted more than 30 percent from the expected value. Analyze the PEM standard to monitor chromatographic resolution, sensitivity, and degradation, primarily for $p, p^{\prime}$-DDT and endrin breakdown during injection. If the breakdown of $p, p^{\prime}$-DDT or endrin exceeds 30 percent when analyzing fraction-2 (this fraction contains endrin, $o, p^{\prime}$ - and $p, p^{\prime}$-DDT, $o, p^{\prime}$ - and $p, p^{\prime}$-DDD among other more polar organic compounds), then terminate the analysis, perform preventive maintenance, and re-analyze the extracts. If the CCV has drifted more than 30 percent, refer to SOP OT0022.0 for guidance (unpublished SOPs are available from the NWQL).

7.7 Report the compound concentration data from the column that produces the lowest concentration, unless it is documented through calibration standards, $\mathrm{CCV}$, or PEM that a specific compound on a specific capillary column is not performing adequately because of compound coelution, degradation, or interference.

7.8 The following compounds are known to coelute on the specified capillary column:

7.8.1 Known coelutions on Rtx-5: $0, p^{\prime}$-DDT and $p, p^{\prime}$-DDD; Heptachlor epoxide and oxychlordane.

7.8.2 Known coelutions on Rtx-1701: cis-Nonachlor and $p, p^{\prime}$-DDD; Oxychlordane and DCPA.

7.9 The following is a typical GC analytical sequence for standards, environmental samples, and quality-control samples:

Hexane wash

PEM

$5 \mathrm{pg} / \mu \mathrm{L}$ calibration standard

$10 \mathrm{pg} / \mu \mathrm{L}$ calibration standard

$20 \mathrm{pg} / \mu \mathrm{L}$ calibration standard

$50 \mathrm{pg} / \mu \mathrm{L}$ calibration standard

$100 \mathrm{pg} / \mu \mathrm{L}$ calibration standard

$200 \mathrm{pg} / \mu \mathrm{L}$ calibration standard

$600 \mathrm{pg} / \mu \mathrm{L}$ PCB calibration standard

$800 \mathrm{pg} / \mu \mathrm{L}$ toxaphene calibration standard 
Method blank

Method spike

SRM

Two environmental samples

CCV

PEM

Five environmental samples

$\mathrm{CCV}$

PEM

Five environmental samples

CCV

PEM

Five environmental samples

$\mathrm{CCV}$

PEM

7.10 Compound identification is confirmed if the compound is detected at the expected retention time on both GC columns. The degree of error associated with the retention time is matrix and compound dependent. The allowable retention-time error is based on the average of three retention times of standards from the initial calibration GC sequence. The quantitative value reported is column dependent.

\section{Calibration}

Compounds are calibrated (and subsequently quantitated in samples) by using results obtained on both capillary columns.

8.1 Multipoint external standard calibration for single-component compounds. Option: The internal standard method of compound calibration and quantitation uses either tetrachloro-m-xylene or decachlorobiphenyl, provided that there are no chromatographic interferences with these compounds. Details of internal standard quantitation are not provided here. In the external standard method described below, tetrachloro-m-xylene or decachlorobiphenyl is used as a retention-time marker to assist in compound identification.

8.1.1 For single-component compounds, calibrate using multipoint curves produced from analysis of the 5 to $200 \mathrm{pg} / \mu \mathrm{L}$ (or other) calibration standards. Regress the peak area of the compound in the standard solution $\left(A_{\mathcal{C}}\right)$ in relation to the mass (in picograms) of the compound in the standard injected using the following simple linear model: 


$$
A_{c}=m \times\left(C_{c} \times V_{1}\right)+b
$$

where $m=$ compound-specific slope, in area per picograms;

$C_{c}=$ concentration of the compound in the standard, in

picograms per microliter;

$V_{1}=$ volume of calibration standard injected into GC/ECD, in microliters; and

$b=$ compound-specific $y$-intercept, in area.

NOTE: Other regression models may be used as appropriate.

8.1.2 For compounds that exhibit coelutions on both analytical columns (for example, $p, p^{\prime}$-DDD), calibrate by using one or more separate standards that contain only one of the coeluting compounds. For example, use separate standards that contain $p, p^{\prime}$-DDD but not coeluting $o, p^{\prime}$-DDT (on Rtx-5), and not coeluting cisnonachlor (on Rtx-1701). Identification and quantification of compounds that coelute on both columns requires careful consideration by the analyst. For example, $p, p^{\prime}$-DDD can be quantified on the Rtx-1701 column if there are no other chlordane components present in the sample (thus suggesting no coeluting cis-nonachlor). In most cases, the compound that coelutes on both columns will need to be reported as an upper limit value, or not reported because of coeluting interference.

8.2 External standard calibration for PCBs and toxaphene. For PCBs and toxaphene, an overall response factor is computed by summing the peak areas for 10 to 15 representative congeners (selected on the basis of adequate peak intensity and separation from other congener, target compound, and interferent peaks) and dividing by the concentration of the PCB or toxaphene standard. For PCBs, a 1:1:1 mixture of Aroclor 1242, 1254, and 1260 at $200 \mathrm{pg} / \mu \mathrm{L}$ each (or $600 \mathrm{pg} / \mu \mathrm{L}$ total concentration) was typically used as the calibration standard. The response factor is calculated by equation 5 :

$$
R F=\frac{\text { Sum of selected congener peak areas in standard }}{C_{m} \times V_{1}}
$$

where $R F=$ response factor, in area per picograms;

$C_{m}=$ total PCB or toxaphene concentration in standard, in picograms per microliter; and

$V_{1}=$ volume of standard injected into $\mathrm{GC} / \mathrm{ECD}$, in microliters.

An average response factor is computed if multilevel calibration standards are used for PCBs and toxaphene. 


\section{Calculations}

9.1 Calculate the concentration of compounds in the sample extract. For the individual compounds, use the compound-specific regression parameters (equation 4) from the calibration curve to calculate the raw amount of compound in the sample extract:

$$
R A=\frac{\left(A_{s}-b\right)}{m \times V_{2}}
$$

where $R A=$ raw amount of compound in sample extract, in picograms

per microliter;

$A_{S}=$ the peak area of the identified component in the sample extract;

$b=$ compound-specific $y$-intercept, in area;

$m=$ compound-specific slope, in area per picograms; and

$V_{2}=$ final volume of extract injected into GC/ECD, in microliters.

9.2 Calculate the concentration of PCBs and toxaphene in the sample. Sum the peak areas for the 10 to $15 \mathrm{PCB}$ or toxaphene congeners in the sample that match the retention times of those peaks selected for the PCB or toxaphene calibration standards. Calculate the raw amount of PCBs or toxaphene in the sample extract, as follows:

$$
R A_{m}=\frac{\text { Sum of selected congener peak areas in sample }}{R F \times V_{2}}
$$

where $R A_{m}=$ raw amount of PCB or toxaphene in sample extract, in picograms per microliter;

$R F=$ the PCB or toxaphene response factor, in area per picograms (calculated from equation 5); and

$V_{2} \quad$ final volume of extract injected into GC/ECD, in microliters.

9.3 Calculate the concentration $\left(C_{S}\right)$ of the identified compound in the sample, in micrograms per kilogram of wet-weight tissue, using

$$
C_{S}=\frac{R A \times V_{3}}{S_{a}}
$$

where $C_{S}=$ concentration of compound in sample, in micrograms per

kilogram (nanograms per gram);

$R A=$ raw amount of compound, in nanograms per milliliter

(picograms per microliter) (calculated from equation 6);

$V_{3}=$ final volume of extract just prior to GC/ECD, in milliliters; and

$S_{a}=$ equivalent weight of tissue injected into the GPC (calculated from equation 3 ). 
NOTE: For PCBs and toxaphene, substitute $R A_{m}$ from equation 7 for $R A$ in equation 8.

9.4 Calculate the percent recovery of the surrogate compounds in each sample, using

$$
R_{a}=\frac{C_{s}}{\left(C_{a} \times V_{a}\right) / S_{w}} \times 100
$$

where $\quad R_{a}=$ recovery of surrogate in sample, in percent;

$C_{S}=$ concentration of surrogate in sample, in nanograms per gram

(= micrograms per kilogram) (calculated from equation 8 );

$C_{a}=$ concentration of compound in the surrogate standard added

to the sample, in nanograms per microliter;

$V_{a}=$ volume of surrogate standard added to the sample, in

microliters; and

$S_{w}=$ weight of sample extracted in grams (use weight recorded in section 6.4).

9.5 Calculate the percent recovery of compounds in reagent spike sample, using

$$
R_{b}=\frac{C_{s}}{\left(C_{b} \times V_{b}\right) / S_{w}} \times 100
$$

where $R_{b}=$ recovery of spiked compound in the reagent spike sample,

in percent;

$C_{S}=$ concentration of compound in reagent spike sample, in nanograms per gram (micrograms per kilogram) (calculated from equation 8);

$C_{b}=$ concentration of compound in organochlorine spike standard added to sample, in nanograms per microliter;

$V_{b}=$ volume of reagent spike standard added to the sample, in microliters; and

$S_{w}=$ weight of sample extracted in grams (use weight recorded in section 6.4).

9.6 Calculate the percent recovery of compounds in SRM sample, using

$$
R_{S R M}=\frac{C_{S}}{C_{S r m}} \times 100
$$

where $R_{S R M}=$ recovery of compound in the SRM sample, in percent;

$C_{S}=$ concentration of compound in SRM sample, in nanograms per gram (micrograms per kilogram)

(calculated from equation 8); and

$C_{s r m}=$ certified concentration of compound in the SRM sample, in nanograms per gram. 
9.7 Calculate the percent breakdown of $p, p^{\prime}$-DDT and endrin on the GC/ECD from injections of the PEM using the following equations:

$$
\text { Percent } p, p^{\prime} \text {-DDT breakdown }=\frac{A_{p, p^{\prime}-\mathrm{DDE}}+A_{p, p^{\prime}-\mathrm{DDD}}}{A_{p, p^{\prime}-\mathrm{DDT}}+A_{p, p^{\prime}-\mathrm{DDD}}+A_{p, p^{\prime}-\mathrm{DDE}}} \times 100
$$

and

$$
\text { Percent endrin breakdown }=\frac{A_{\text {endrin aldehyde }}+A_{\text {endrin ketone }}}{A_{\text {endrin }}+A_{\text {endrin aldehyde }}+A_{\text {endrin ketone }}} \times 100
$$

where $A_{\text {compound }}=$ peak area of given compound in the PEM chromatogram.

9.8 Compute the CCV percent difference.

9.8.1 Calculate the raw amount for each compound in the CCV standard $\left(R A_{C C V}\right)$ using equation 6.

9.8.2 Calculate the percent difference between the determined and expected $\mathrm{CCV}$ concentrations, using

$$
\mathrm{CCV} \text { percent difference }=\frac{R A_{\mathcal{c c v}-C_{e}}}{C_{e}} \times 100
$$

where $R A_{c c v}=$ calculated raw amount of compound in CCV standard, in picograms per microliter; and

$C_{e}=$ expected concentration of compound in CCV standard, in picograms per microliter.

\section{Reporting of results}

Report concentrations of compounds as follows: less than $10 \mu \mathrm{g} / \mathrm{kg}$, two significant figures; 10 to $1,000 \mu \mathrm{g} / \mathrm{kg}$, three significant figures. Report results less than $5.0 \mu \mathrm{g} / \mathrm{kg}$ as "less than method reporting limit." 


\section{DISCUSSION OF RESULTS}

\section{Method Performance}

Method performance was evaluated by analyzing samples of nonspiked homogenized whole-body fish tissue, homogenized corbicula tissue, as well as samples of the same tissues spiked at two different concentrations. Each sample was evaluated using seven replicates. In addition, seven replicates at two concentrations of a reagent spike were analyzed. Seven replicates of NIST SRM-1588 cod liver oil were analyzed as part of the evaluation of method accuracy. To further validate the analytical method, two samples from the U.S. Fish and Wildlife Service round-robin evaluation were analyzed in duplicate, and a USEPA quality-control sample was analyzed in quadruplicate.

The method performance data from nonmatrix spikes, matrix spikes, and SRM analyses are listed in the Supplement, tables 2 through 12. The compounds are listed in order of detection on Rtx-5.

Because of the high background levels of some of the method compounds in the sample that was selected for the $30-$ and $100-\mu \mathrm{g} / \mathrm{kg}$ matrix spike, a second set of experiments was conducted on a separate sample spiked at $40 \mu \mathrm{g} / \mathrm{kg}$ to produce performance data at a low concentration. Unfortunately, the second sample selected also had high concentrations of selected method compounds that precluded establishing performance data at this level. No further attempt was made to locate a sample with suitable background concentrations and repeat the recovery experiments because of the length of time required to produce method performance data.

The performance data presented in tables 2 through 16 (see Supplement) indicate that this method will provide accurate and precise concentration data for all method compounds. However, some method compounds may present problems in analysis; an example of a problem is listed in table 4 . The concentration data for $o, p^{\prime}-$ and $p, p^{\prime}$-DDD have percent RSDs (relative standard deviations) that are greater than 60 percent. The concentration data for $o, p^{\prime}$ - and $p, p^{\prime}$-DDD are lower in determinations $A$ and $B$ than for determinations $C, D, E$, and F. Initially this limited data set indicates that a problem exists with the samples. If this were the case, all concentration data for all method compounds would have percent RSDs that are comparable to those of the $o, p^{\prime}$ - and $p, p^{\prime}$-DDD. With the exception of these two compounds, the precision of the method compounds is acceptable (percent $\mathrm{RSD}<23$ percent).

There are two possibilities that would explain the data. First, there are unknown compounds that are coeluting with $o, p^{\prime}$ - and $p, p^{\prime}$-DDD in determinations $\mathrm{C}, \mathrm{D}, \mathrm{E}$, and $\mathrm{F}$ that account for their higher concentrations. Second, $0, p^{\prime}-$ and $p, p^{\prime}-$ DDT are susceptible to thermal degradation and may thermally degrade to $o, p^{\prime}$ - and $p, p^{\prime}$-DDD inside the GC injection port when it is contaminated. These data indicate that thermal degradation indeed is occurring. In determinations $\mathrm{A}$ and $\mathrm{B}, o, p^{\prime}-$ and $p, p^{\prime}$-DDT are not thermally degrading to $o, p^{\prime}-$ and $p, p^{\prime}$-DDD (table 4). Higher reported concentrations of $o, p^{\prime}$ - and $p, p^{\prime}$-DDD in determinations $C, D, E$, and F 
indicate that $o, p^{\prime}$ - and $p, p^{\prime}$-DDT are thermally degrading to their respective DDD components upon injection of the sample extract. This line of reasoning can be applied to table 12, which lists percent recovery from the NIST SRM-1588. The performance evaluation mix was not analyzed during the method-performance phase of this project. This type of problem is identified and corrected by examining the results of the PEM standard that is analyzed after every fifth environmental sample.

To further validate this tissue methodology, the NWQL participated in several round-robin studies sponsored by the U.S. Fish and Wildlife Service and the USEPA. The samples from the U.S. Fish and Wildlife service were homogenized fish tissue. The samples from the USEPA were freeze-dried and mixed with sodium sulfate. The results from other laboratories that participated in the Fish and Wildlife Service round-robin study and the results produced by NWQL using this method are listed in tables 13a and 13b (see Supplement). The study consisted of two homogenized fish-tissue samples that were analyzed for the following compounds: alpha- and gamma-HCH, hexachlorobenzene, heptachlor epoxide, oxychlordane, cisand trans-chlordane, cis- and trans-nonachlor, $o, p^{\prime}$ - and $p, p^{\prime}-\mathrm{DDE}, o, p^{\prime}$ - and $p, p^{\prime}-\mathrm{DDD}$, $o, p^{\prime}$ - and $p, p^{\prime}$-DDT, dieldrin, endrin, mirex, total PCBs, and toxaphene. On the basis of a duplicate concentration for each sample, the data produced by NWQL from the U.S. Fish and Wildlife samples fall within one standard deviation of the mean for all method compounds. When duplicates are not averaged but are considered as individual analyses, about 80 percent of all data fell within one standard deviation, and 100 percent of the data fell within two standard deviations. The calculated range, provided by the USFWS, is based on the individual analyses from all participating laboratories.

The results of the USEPA quality-control samples are listed in table 14 (see Supplement). Four replicate samples contained cis- and trans-chlordane, cis- and trans-nonachlor, oxychlordane, total chlordane (defined as the sum of cis- and transchlordane, cis- and trans-nonachlor, and oxychlordane), $p, p^{\prime}$-DDE, $p, p^{\prime}-\mathrm{DDD}, p, p^{\prime}-$ DDT, total DDX (defined as the sum of $p, p^{\prime}-\mathrm{DDE}, p, p^{\prime}-\mathrm{DDD}, p, p^{\prime}-\mathrm{DDT}$ ), and percentage of lipid. The total chlordane and DDX values are within the acceptable range as determined by the USEPA. The precision of the total chlordane and DDX measurements is within one standard deviation. Although the average percentage of lipid is outside the acceptable range, this value is directly dependent on the solvent used for extraction. The samples analyzed by NWQL were extracted by methylene chloride. The reported values were from a hexane extraction.

\section{Method Detection Limits}

Method detection limits were estimated with data from the $2.5-\mu \mathrm{g} / \mathrm{kg}$ reagent spikes and homogenized fish tissue that were fortified at the $2.0-\mu \mathrm{g} / \mathrm{kg}$ level. Matrix based method detection limits were determined on a fish homogenate chosen from submitted samples that contained low levels of contaminants. The method detection limits listed in tables 15 and 16 (see Supplement) are single calibration MDLs 
determined in two matrices. These detection limits are not used as method reporting limits. They neither account for the range of lipid composition, lipid concentration, and variety of aquatic tissues that are routinely analyzed, nor the dayto-day variation in instrument performance. The method detection limits were determined according to the U.S. Environmental Protection Agency (1992, p. 565-567).

\section{QUALITY ASSURANCE}

Process the samples and analyze in a set consisting of 16 samples-- 12 environmental samples and 4 quality-control samples. The quality-control samples consist of a sodium sulfate blank, a reagent spike, SRM, and a duplicate environmental sample. Add a surrogate spike to all samples, including QC samples, prior to extraction. The amount to be added is established in paragraph 5.10.2. Add retention-time markers to all samples, including QC samples, prior to GC analysis. The amount to be added is established in paragraph 5.10.3.

\section{Interpretation of Laboratory Quality-Control Data}

The percentage of surrogate recovery is intended to provide data on the overall performance of the analytical method as it relates to a specific sample.

Environmental data is not to be corrected for surrogate recoveries. If any portion of the method fails prior to fractionation on the alumina silica column, the failure will be reflected in low recoveries of both surrogates. If the surrogate recovery is within three sigma of the average surrogate recovery (the control limits), the method is within analytical control for that sample. If the recoveries of both surrogates from both GC columns are greater than three sigma of the average surrogate recovery, this result might indicate coeluting interferences with the surrogate or an unknown matrix effect. This result might not bias the reported concentrations of the method compound, but the chromatogram needs to be reviewed thoroughly. If the percentage of recovery of both surrogates falls below the lower three-sigma control limit, the preparation for that sample is considered out of analytical control. As a result, the sample will need to be reextracted and reanalyzed. If the surrogate from a single fraction is less than 30 percent recovery, the extract is to be reanalyzed.

Reagent spike recovery data are used to monitor the overall performance of the analytical method. The reagent spike percent recoveries are not influenced by matrix effects. Reagent spike recoveries outside of three sigma might indicate that the analytical data for the entire set are not acceptable, and the set needs to be reextracted and reanalyzed.

To further evaluate method performance, the analyst examines the SRM and surrogate recoveries of all samples in the set. If the reagent spike recoveries, SRM, and surrogate recoveries are not within established guidelines, reevaluate the entire 
set and reextract and reanalyze. If the reagent spike, SRM, and surrogate recoveries are within established guidelines, the analytical data are considered to be acceptable. The surrogate and reagent spike data are never used to correct environmental data.

\section{CONCLUSIONS}

On the basis of data presented, this analytical method can be used routinely for the determination of chlorinated pesticides in whole-body-fish and corbicula tissue at low microgram-per-kilogram concentrations. At present (1995), method reporting limits are set at $5 \mu \mathrm{g} / \mathrm{kg}$ wet weight for chlorinated compounds, $50 \mu \mathrm{g} / \mathrm{kg}$ for polychlorinated biphenyls, and $200 \mu \mathrm{g} / \mathrm{kg}$ for toxaphene. Reporting limits are subject to change depending on background interferences, limitation in sample size, matrix effects, or high levels of other compounds, such as PCBs in the sample extract.

\section{REFERENCES CITED}

Barthel, W.F., Hawthorne, J.C., Ford, J.H., Bolton, G.C., McDowell, L.L., Grissinger, E.H., and Parsons, D.A., 1969, Pesticide residues in sediments of the lower Mississippi River and its tributaries: Pesticides Monitoring Journal, v. 3, no. 1, p. 8-66.

Crawford, J.K., and Luoma, S.N., 1993, Guidelines for studies of contaminants in biological tissues for the National Water-Quality Assessment Program: U.S. Geological Survey Open-File Report 92-494, 69 p.

Jaffe, Rudolf, Stemmler, E.A., Eitzer, B.D., and Hites, R.A., 1985, Anthropogenic, polyhalogenated, organic compounds in sedentary fish from Lake Huron and Lake Superior tributaries and embayments: Journal of Great Lakes Research, v. 11 , no. 2, p. 156-162.

Laska, A.L., Bartell, C.K., and Laseter, J.L., 1976, Distribution of hexachlorobenzene and hexachlorobutadiene in water, soil, and selected aquatic organisms along the lower Mississippi River, Louisiana: Bulletin of Environmental Contamination and Toxicology, v. 15, no. 5, p. 535-542.

Leiker, T.J., Rostad, C.E., Barnes, C.R., and Pereira, W.E., 1991, A reconnaissance study of halogenated organic compounds in catfish from the lower Mississippi River and its major tributaries: Chemosphere, v. 23, no. 7, p. 817-829.

McNair, H.M., and Bonelli, E.J., 1969, Basic gas chromatography (5th ed.): Berkeley, Calif., Consolidated Printers, 306 p.

Oliver, B.G., and Niimi, A.J., 1985, Bioconcentration factors of some halogenated organics for rainbow trout: Limitations in their use for prediction of environmental residues: Environmental Science and Technology, v. 19, p. 842-849. 
Pereira, W.E., Rostad, C.E., Chiou, C.T., Brinton, T.I., Barber, L.B., II, Demcheck, D.K., and Demas, C.R., 1988, Contamination of estuarine water, biota, and sediment by halogenated organic compounds: A field study: Environmental Science and Technology, v. 22, no. 7, p. 772-778.

Sabourin, T.D., Stickle, W.B., Michot, T.C., Villars, C.E., Garton, D.W., and Mushinsky, H.R., 1984, Organochlorine residue levels in Mississippi River water snakes in southern Louisiana: Bulletin of Environmental Contamination and Toxicology, v. 32, p. 460-468.

Swackhamer, D.L., and Hites, R.A., 1988, Occurrence and bioaccumulation of organochlorine compounds in fishes from Siskwit Lake, Isle Royale, Lake Superior: Environmental Science and Technology, v. 22, no. 5, p. 543-548.

U.S. Environmental Protection Agency, 1990, Test methods for evaluating solid waste, SW-846, v. IB, Laboratory manual, physical/chemical methods: Washington, D.C., Office of Solid Waste and Emergency Response, Method 8000A--Gas chromatography, rev. 1, p. 8000A 1-16.

1992, Guidelines establishing test procedures for the analysis of pollutants (App. B to Part 136, Definition and procedures for the determination of the method detection limit): U.S. Code of Federal Regulations, Title 40, revised as of July 1, 1992, p. 565-567.

Wershaw, R.L., Fishman, M.J., Grabbe, R.R., and Lowe, L.E., eds., 1987, Methods for the determination of organic substances in water and fluvial sediments: U.S. Geological Survey Techniques of Water-Resources Investigations, book 5, chap. A3, 80 p.

Winger, P.V., and Andreasen, J.K., 1985, Contaminant residues in fish and sediments from lakes in the Atchafalaya River Basin (Louisiana): Archives of Environmental Contamination and Toxicology, v. 14, no. 5, p. 579-586. 

SUPPLEMENT: METHOD PERFORMANCE DATA 

Table 2. Concentration data of nonspiked whole-body fish tissue used for 40-microgram-per-kilogram spike

$[\mu \mathrm{g} / \mathrm{kg}$, micrograms per kilogram; Std. dev., standard deviation; RSD, relative standard deviation; <, less than]

\begin{tabular}{|c|c|c|c|c|c|c|c|c|c|c|}
\hline \multirow[t]{2}{*}{ Compound } & \multicolumn{7}{|c|}{ Concentration units $(\mu \mathrm{g} / \mathrm{kg}$ wet weight) } & \multirow[t]{2}{*}{ Mean } & \multirow{2}{*}{$\begin{array}{l}\text { Std. } \\
\text { dev. }\end{array}$} & \multirow{2}{*}{$\begin{array}{c}\text { RSD } \\
\text { (percent }\end{array}$} \\
\hline & $\mathrm{A}$ & $\overline{\mathrm{B}}$ & $\mathrm{C}$ & $\mathrm{D}$ & $\mathrm{E}$ & $\mathrm{F}$ & $\bar{G}$ & & & \\
\hline alpha-HCH & 4.8 & 8.6 & 10.2 & 11.6 & 11.4 & 9.3 & 6.8 & 9.0 & 2.5 & 27.7 \\
\hline Hexachlorobenzene & $<5$ & $<5$ & $<5$ & $<5$ & $<5$ & $<5$ & $<5$ & & & \\
\hline Pentachloroanisole & $<5$ & $<5$ & $<5$ & $<5$ & $<5$ & $<5$ & $<5$ & & & \\
\hline beta-HCH & 3.3 & 4.9 & 4.9 & 5.0 & 4.7 & 3.9 & 3.0 & 4.2 & .8 & 19.7 \\
\hline gamma-HCH & 5.5 & 7.3 & 6.7 & 8.0 & 6.9 & 5.5 & 4.4 & 6.3 & 1.2 & 19.6 \\
\hline delta-HCH & 22.1 & 27.6 & 30.9 & 41.1 & 37.3 & 29.0 & 27.3 & 30.8 & 6.4 & 21.0 \\
\hline Heptachlor & $<5$ & $<5$ & $<5$ & $<5$ & $<5$ & $<5$ & $<5$ & & & \\
\hline Ald̂́rin & $<5$ & $<5$ & $<5$ & $<5$ & $<5$ & $<5$ & $<5$ & & & \\
\hline DCPA & 4.8 & 11.6 & 10.8 & 8.9 & 9.8 & 8.9 & 6.8 & 8.8 & 2.4 & 26.7 \\
\hline Heptachlor epoxide & $<5$ & $<5$ & $<5$ & $<5$ & $<5$ & $<5$ & $<5$ & & & \\
\hline Oxychlordane & $<5$ & $<5$ & $<5$ & $<5$ & $<5$ & $<5$ & $<5$ & & & \\
\hline trans-Chlordane & $<5$ & $<5$ & $<5$ & $<5$ & $<5$ & $<5$ & $<5$ & & & \\
\hline$o, p^{\prime}-\mathrm{DDE}$ & $<5$ & $<5$ & $<5$ & $<5$ & $<5$ & $<5$ & $<5$ & & & \\
\hline cis-Chlordane & 19.5 & 24.1 & 27.9 & 37.9 & 33.2 & 27.3 & 22.5 & 27.5 & 6.3 & 23.1 \\
\hline trans-Nonachlor & 17.0 & 14.5 & 17.6 & 17.0 & 17.3 & 19.0 & 11.3 & 16.2 & 2.5 & 15.7 \\
\hline Dieldrin & 128 & 124 & 135 & 138 & 137 & 141 & 91 & 128 & 17.1 & 13.4 \\
\hline$p, p^{\prime}-\mathrm{DDE}$ & 1,267 & 880 & 862 & 831 & 846 & 847 & 876 & 916 & 156 & 17.0 \\
\hline$o, p^{\prime}-\mathrm{DDD}$ & 33.1 & 31.2 & 37.4 & 40.7 & 34.1 & 35.1 & 22.8 & 33.5 & 5.6 & 16.8 \\
\hline Endrin & 9.5 & 18.2 & 11.5 & 24.0 & 14.1 & 13.5 & 11.3 & 14.6 & 5.0 & 34.4 \\
\hline cis-Nonachlor & 5.5 & 6.0 & 6.9 & 6.7 & 7.2 & 7.2 & 4.6 & 6.3 & 1.0 & 15.9 \\
\hline$p, p^{\prime}-\mathrm{DDD}$ & 335 & 308 & 338 & 336 & 360 & 362 & 246 & 326 & 39.9 & 12.2 \\
\hline$o, p^{\prime}-\mathrm{DDT}$ & $<5$ & $<5$ & $<5$ & $<5$ & $<5$ & $<5$ & $<5$ & & & \\
\hline$p, p^{\prime}-\mathrm{DDT}$ & 199 & 181 & 186 & 176 & 153 & 172 & 123 & 170 & 25.1 & 14.7 \\
\hline$o, p^{\prime}$-Methoxychlor & $<5$ & $<5$ & $<5$ & $<5$ & $<5$ & $<5$ & $<5$ & & & \\
\hline$p, p^{\prime}$-Methoxychlor & $<5$ & $<5$ & $<5$ & $<5$ & $<5$ & $<5$ & $<5$ & & & \\
\hline Mirex & $<5$ & $<5$ & $<5$ & $<5$ & $<5$ & $<5$ & $<5$ & & & \\
\hline
\end{tabular}


Table 3. Percent recovery of 40-microgram-per-kilogram spike in homogenized whole-body fish tissue

[Std. dev., standard deviation; RSD, relative standard deviation; ND, not detected; NS, not spiked, standards not available; NR, not reported, background concentrations greater than spike]

\begin{tabular}{|c|c|c|c|c|c|c|c|c|c|c|}
\hline \multirow[t]{2}{*}{ Compound } & \multicolumn{7}{|c|}{ Recovery of individual compounds, in percent } & \multirow[t]{2}{*}{ Mean } & \multirow{2}{*}{$\begin{array}{l}\text { Std. } \\
\text { dev. }\end{array}$} & \multirow{2}{*}{$\begin{array}{c}\text { RSD } \\
\text { (percent) }\end{array}$} \\
\hline & $\mathrm{A}$ & $\mathrm{B}$ & $\mathrm{C}$ & $\overline{\mathrm{D}}$ & $\mathrm{E}$ & $F$ & $\mathrm{G}$ & & & \\
\hline alpha-HCH & ND & ND & ND & ND & ND & ND & ND & & & \\
\hline Hexachlorobenzene & 87 & 88 & 94 & 92 & 106 & 97 & 99 & 95 & 7 & 7 \\
\hline Pentachloroanisole & NS & NS & NS & NS & NS & NS & NS & & & \\
\hline beta-HCH & ND & ND & ND & ND & ND & ND & ND & & & \\
\hline gamma-HCH & 52 & 64 & 90 & 22 & 33 & 20 & 25 & 44 & 26 & 60 \\
\hline delta-HCH & ND & ND & ND & ND & ND & ND & ND & & & \\
\hline Heptachlor & 89 & 91 & 92 & 89 & 102 & 92 & 96 & 93 & 5 & 5 \\
\hline Aldrin & 61 & 65 & 78 & 76 & 88 & 90 & 61 & 74 & 12 & 16 \\
\hline DCPA & 73 & 88 & 125 & 132 & 149 & 136 & 150 & 122 & 30 & 25 \\
\hline Heptachlor epoxide & 76 & 92 & 126 & 119 & 149 & 137 & 150 & 121 & 28 & 23 \\
\hline Oxychlordane & NS & NS & NS & NS & NS & NS & NS & & & \\
\hline trans-Chlordane & 61 & 65 & 68 & 66 & 74 & 74 & 76 & 69 & 6 & 8 \\
\hline$o, p^{\prime}-\mathrm{DDE}$ & NR & NR & NR & NR & NR & NR & NR & & & \\
\hline cis-Chlordane & 67 & 78 & 82 & 76 & 90 & 88 & 89 & 81 & 8 & 10 \\
\hline trans-Nonachlor & 60 & 76 & 83 & 82 & 82 & 83 & 95 & 80 & 11 & 13 \\
\hline Dieldrin & NR & NR & NR & NR & NR & NR & NR & & & \\
\hline$p, p^{\prime}-\mathrm{DDE}$ & NR & NR & NR & NR & NR & NR & $N R$ & & & \\
\hline$o, p^{\prime}-\mathrm{DDD}$ & 31 & 41 & 48 & 49 & 62 & 59 & 67 & 51 & 13 & 25 \\
\hline Endrin & 89 & 93 & 98 & 94 & 88 & 97 & 91 & 93 & 4 & 4 \\
\hline cis-Nonachlor & 68 & 78 & 78 & 74 & 87 & 97 & 91 & 82 & 10 & 12 \\
\hline$p, p^{\prime}-\mathrm{DDD}$ & NR & NR & NR & NR & NR & NR & NR & & & \\
\hline$o, p^{\prime}-\mathrm{DDT}$ & NR & NR & NR & NR & NR & NR & NR & & & \\
\hline$p, p^{\prime}-\mathrm{DDT}$ & NR & NR & NR & NR & $N R$ & NR & NR & & & \\
\hline$o, p^{\prime}$-Methoxychlor & 94 & 108 & 100 & 102 & 94 & 85 & 76 & 94 & 11 & 11 \\
\hline$p, p^{\prime}$-Methoxychlor & 101 & 119 & 137 & 127 & 137 & 132 & 143 & 128 & 14 & 11 \\
\hline Mirex & 100 & 108 & 108 & 105 & 120 & 109 & 111 & 109 & 6 & 6 \\
\hline Lipid & 11.8 & 9.7 & 9.2 & 10.3 & 9.0 & 10.6 & 9.6 & 10 & 1 & 10 \\
\hline
\end{tabular}


Table 4. Concentration data of nonspiked whole-body fish tissue used for 30- and 100-microgram-per-kilogram spike

$[\mu \mathrm{g} / \mathrm{kg}$, micrograms per kilogram; Std. dev., standard deviation; RSD, relative standard deviation; <, less than]

\begin{tabular}{|c|c|c|c|c|c|c|c|c|c|}
\hline \multirow[t]{2}{*}{ Compound } & \multicolumn{6}{|c|}{ Concentration units ( $\mu \mathrm{g} / \mathrm{kg}$ wet weight) } & \multirow[t]{2}{*}{ Mean } & \multirow{2}{*}{$\begin{array}{l}\text { Std. } \\
\text { dev. }\end{array}$} & \multirow{2}{*}{$\begin{array}{c}\text { RSD } \\
\text { (percent) }\end{array}$} \\
\hline & $\mathrm{A}$ & $\mathrm{B}$ & $\mathrm{C}$ & $\mathrm{D}$ & $E$ & $\mathrm{~F}$ & & & \\
\hline alpha-HCH & $<5$ & $<5$ & $<5$ & $<5$ & $<5$ & $<5$ & & & \\
\hline Hexachlorobenzene & 5 & 4.8 & 5.3 & 4.9 & 6.3 & 4.3 & 5.1 & 0.7 & 14 \\
\hline Pentachloroanisole & $<5$ & $<5$ & $<5$ & $<5$ & $<5$ & $<5$ & & & \\
\hline beta-HCH & 2.4 & 7.5 & 7 & 6.8 & 8.2 & 5.4 & 6.2 & 2.1 & 34 \\
\hline gamma-HCH & $<5$ & $<5$ & $<5$ & $<5$ & $<5$ & $<5$ & & & \\
\hline delta-HCH & $<5$ & $<5$ & $<5$ & $<5$ & $<5$ & $<5$ & & & \\
\hline Heptachlor & $<5$ & $<5$ & $<5$ & $<5$ & $<5$ & $<5$ & & & \\
\hline Aldrin & $<5$ & $<5$ & $<5$ & $<5$ & $<5$ & $<5$ & & & \\
\hline DCPA & 7.4 & 4.7 & 4.7 & 6.7 & 6 & 7.8 & 6.2 & 1.3 & 21 \\
\hline Heptachlor epoxide & 11.2 & 11.4 & 10.9 & 10.6 & 14.1 & 9.8 & 11.3 & 1.5 & 13 \\
\hline Oxychlordane & $<5$ & $<5$ & $<5$ & $<5$ & $<5$ & $<5$ & & & \\
\hline trans-Chlordane & 6.3 & 5.8 & 7.2 & 5.8 & 8.1 & 6.1 & & & \\
\hline$o, p^{\prime}-\mathrm{DDE}$ & 11.2 & 11.1 & 10.6 & 9.5 & 10.9 & 9.4 & 10.5 & .8 & 7.6 \\
\hline cis-Chlordane & 18.2 & 17 & 16.9 & 16.9 & 21.6 & 15.4 & 17.7 & 2.1 & 12 \\
\hline trans-Nonachlor & 36.5 & 36.4 & 32.8 & 34.6 & 42.4 & 30.1 & 35.4 & 4.2 & 12 \\
\hline Dieldrin & 162 & 161 & 114 & 116 & 130 & 96 & 130 & 27 & 21 \\
\hline$p, p^{\prime}-\mathrm{DDE}$ & 1,470 & 1,583 & 894 & 1,282 & 1,293 & 922 & 1,240 & 281 & 23 \\
\hline$o, p^{\prime}-\mathrm{DDD}$ & 8.1 & 7.2 & 48 & 47.9 & 59.3 & 42.3 & 35.5 & 22.3 & 63 \\
\hline Endrin & 16.6 & 15.3 & 19.5 & 8.1 & 16.3 & 10.7 & 14.4 & 4.2 & 29 \\
\hline cis-Nonachlor & 10.7 & 9.8 & 11.6 & 8.7 & 13.4 & 9.2 & 10.6 & 1.8 & 17 \\
\hline$p, p^{\prime}-\mathrm{DDD}$ & 36 & 35 & 405 & 411 & 508 & 366 & 293 & 205 & 70 \\
\hline$o, p^{\prime}-\mathrm{DDT}$ & 18.6 & 15.7 & 21.5 & 21.1 & 26.6 & 18 & 20.2 & 3.8 & 19 \\
\hline$p, p^{\prime}-\mathrm{DDT}$ & 331 & 317 & 274 & 291 & 366 & 257. & 306 & 40 & 13 \\
\hline $0, p^{\prime}$-Methoxychlor & $<5$ & $<5$ & $<5$ & $<5$ & $<5$ & $<5$ & & & \\
\hline$p, p^{\prime}$-Methoxychlor & $<5$ & $<5$ & $<5$ & $<5$ & $<5$ & $<5$ & & & \\
\hline Mirex & $<5$ & $<5$ & $<5$ & $<5$ & $<5$ & $<5$ & & & \\
\hline
\end{tabular}


Table 5. Percent recovery of 30-microgram-per-kilogram spike in homogenized whole-body fish tissue

[Std. dev., standard deviation; RSD, relative standard deviation; ND, not detected;

NS, not spiked, standards not available; NR, not reported, background concentrations greater than spike]

\begin{tabular}{|c|c|c|c|c|c|c|c|c|c|c|}
\hline \multirow[t]{2}{*}{ Compound } & \multicolumn{7}{|c|}{ Recovery of individual compounds, in percent } & \multirow[t]{2}{*}{ Mean } & \multirow{2}{*}{$\begin{array}{l}\text { Std. } \\
\text { dev. }\end{array}$} & \multirow{2}{*}{$\begin{array}{c}\text { RSD } \\
\text { (percent) }\end{array}$} \\
\hline & A & $\mathrm{B}$ & $\mathrm{C}$ & $\mathrm{D}$ & $\mathrm{E}$ & $\mathbf{F}$ & $\mathrm{G}$ & & & \\
\hline alpha-HCH* & 98 & 98 & $<5$ & 113 & 103 & 61 & 102 & 96 & 18 & 19 \\
\hline Hexachlorobenzene & 89 & 93 & 93 & 108 & 109 & 67 & 107 & 95 & 15 & 16 \\
\hline Pentachloroanisole & NS & NS & NS & NS & NS & NS & NS & & & \\
\hline beta-HCH & 88 & 62 & 62 & 88 & 93 & 59 & 92 & 78 & 16 & 20 \\
\hline gamma-HCH & 82 & 88 & 88 & 107 & 34 & 80 & 34 & 73 & 28 & 39 \\
\hline delta-HCH & 69 & 82 & 82 & 106 & 99 & 48 & 98 & 84 & 20 & 24 \\
\hline Heptachlor & 92 & 92 & 92 & 103 & 112 & 65 & 110 & 95 & 16 & 17 \\
\hline Aldrin & 78 & 76 & 76 & 90 & 91 & 52 & 90 & 79 & 14 & 18 \\
\hline $\mathrm{DCPA}^{*}$ & 117 & 90 & ND & 67 & 106 & 78 & 104 & 94 & 19 & 20 \\
\hline Heptachlor epoxide & 53 & 48 & ND & 61 & 65 & 23 & 66 & 53 & 16 & 31 \\
\hline Oxychlordane & NS & NS & NS & NS & NS & NS & NS & & & \\
\hline trans-Chlordane* & 81 & 78 & ND & 93 & 95 & 53 & 82 & 80 & 15 & 19 \\
\hline $0, p^{\prime}-\mathrm{DDE}$ & 56 & 41 & 87 & 43 & 47 & 40 & 45 & 51 & 17 & 32 \\
\hline cis-Chlordane & 95 & 94 & 94 & 111 & 121 & 45 & 119 & 97 & 26 & 27 \\
\hline trans-Nonachlor & 105 & 108 & 108 & 131 & 143 & 86 & 140 & 117 & 21 & 18 \\
\hline Dieldrin & NR & NR & NR & NR & NR & NR & NR & & & \\
\hline$p, p^{\prime}-\mathrm{DDE}$ & NR & NR & NR & NR & NR & NR & NR & & & \\
\hline$o, p^{\prime}-\mathrm{DDD}$ & NR & NR & NR & NR & NR & NR & NR & & & \\
\hline Endrin & 68 & 68 & 68 & 94 & 119 & 62 & 117 & 85 & 25 & 29 \\
\hline cis-Nonachlor & 29 & 27 & 27 & 34 & 40 & 17 & 39 & 30 & 8 & 26 \\
\hline$p, p^{\prime}-\mathrm{DDD}$ & NR & NR & NR & NR & NR & NR & NR & & & \\
\hline$o, p^{\prime}-\mathrm{DDT}$ & 84 & 84 & 84 & 96 & 115 & 61 & 113 & 91 & 19 & 21 \\
\hline$p, p^{\prime}-\mathrm{DDT}$ & NR & NR & NR & NR & NR & NR & NR & & & \\
\hline $0, p^{\prime}$-Methoxychlor & 111 & 120 & ND & 149 & 140 & 109 & 137 & 127 & 17 & 13 \\
\hline$p, p^{\prime}$-Methoxychlor & 72 & 78 & 78 & 93 & 94 & 52 & 92 & 80 & 18 & 19 \\
\hline Mirex & 108 & 103 & ND & 116 & 118 & 75 & 116 & 106 & 16 & 15 \\
\hline
\end{tabular}

${ }^{*} n=6$; all others $n=7$. 
Table 6. Percent recovery of 100-microgram-per-kilogram spike in homogenized whole-body fish tissue

[Std. dev., standard deviation; RSD, relative standard deviation; ND, not detected; NR, not reported, background concentrations greater than spike]

\begin{tabular}{|c|c|c|c|c|c|c|c|c|c|}
\hline \multirow[t]{2}{*}{ Compound } & \multicolumn{6}{|c|}{ Recovery of individual compounds, in percent } & \multirow[t]{2}{*}{ Mean } & \multirow{2}{*}{$\begin{array}{l}\text { Std. } \\
\text { dev. }\end{array}$} & \multirow{2}{*}{$\begin{array}{c}\text { RSD } \\
\text { (percent) }\end{array}$} \\
\hline & $\mathrm{A}$ & B & $\mathrm{C}$ & $\mathrm{D}$ & $\mathrm{E}$ & $\mathrm{F}$ & & & \\
\hline alpha-HCH & 100 & 103 & 102 & 104 & 106 & 87 & 100 & 7 & 7 \\
\hline Hexachlorobenzene & 79 & 77 & 86 & 81 & 88 & 66 & 80 & 8 & 10 \\
\hline Pentachloroanisole & 97 & 95 & 103 & 98 & 104 & 80 & 96 & 9 & 9 \\
\hline beta-HCH & 141 & 80 & 160 & 83 & 89 & 66 & 103 & 38 & 37 \\
\hline gamma-HCH & 80 & 87 & 83 & 92 & 93 & 70 & 84 & 8 & 10 \\
\hline delta-HCH & 90 & 98 & 94 & 104 & 104 & 82 & 95 & 8 & 9 \\
\hline Heptachlor & 80 & 86 & 84 & 84 & 84 & 70 & 81 & 6 & 7 \\
\hline Aldrin & 96 & 93 & 86 & 99 & 96 & 81 & 92 & 7 & 8 \\
\hline DCPA $^{*}$ & 108 & 111 & 118 & 108 & 97 & ND & 108 & 8 & 7 \\
\hline Heptachlor epoxide & 80 & 86 & 84 & 84 & 84 & 70 & 81 & 6 & 7 \\
\hline Oxychlordane & 96 & 93 & 86 & 99 & 96 & 81 & 92 & 7 & 8 \\
\hline trans-Chlordane* & 108 & 111 & 118 & 108 & 97. & ND & 108 & 8 & 7 \\
\hline$o, p^{\prime}-\mathrm{DDE}^{*}$ & 29 & 24 & 31 & 40 & 39 & ND & 33 & 7 & 20 \\
\hline cis-Chlordane ${ }^{*}$ & 72 & 70 & 74 & 81 & 89 & ND & 77 & 8 & 10 \\
\hline trans-Nonachlor* & 96 & 55 & 88 & 73 & 77 & ND & 78 & 16 & 20 \\
\hline Dieldrin* & 86 & 105 & 122 & 102 & 118 & ND & 107 & 14 & 13 \\
\hline$p, p^{\prime}-\mathrm{DDE}$ & NR & NR & NR & NR & NR & NR & & & \\
\hline $0, p^{\prime}-\mathrm{DDD}^{*}$ & 93 & 103 & 104 & 102 & 98 & ND - & 100 & 5 & 5 \\
\hline Endrin* & 99 & 107 & 89 & 119 & 95 & $\mathrm{ND}$ & 102 & 11 & 11 \\
\hline cis-Nonachlor* & 91 & 41 & 93 & 97 & 94 & ND & 83 & 24 & 28 \\
\hline$p, p^{\prime}-\mathrm{DDD}$ & NR & NR & NR & NR & NR & NR & & & \\
\hline$o, p^{\prime}-\mathrm{DDT}$ & $\mathrm{ND}$ & $\mathrm{ND}$ & $\mathrm{ND}$ & ND & $\mathrm{ND}$ & $\mathrm{ND}$ & & & \\
\hline$p, p^{\prime}-\mathrm{DDT}$ & NR & NR & NR & NR & NR & NR & & & \\
\hline$o, p^{\prime}$-Methoxychlor* & 93 & 72 & 84 & 80 & 82 & ND & 82 & 8 & 9 \\
\hline$p, p^{\prime}$-Methoxychlor & 85 & 64 & 78 & 75 & 83 & $\mathrm{ND}$ & 77 & 8 & 11 \\
\hline Mirex* & 89 & 76 & 79 & 80 & 80 & $\mathrm{ND}$ & 81 & 5 & 6 \\
\hline Lipid & 40.2 & 34.6 & 32.5 & 33.9 & 28.0 & 37.4 & 34 & 4 & 12 \\
\hline
\end{tabular}


Table 7. Concentration data of nonspiked corbicula tissue used for 5- and 40-microgram-per-kilogram spike

$[\mu \mathrm{g} / \mathrm{kg}$, micrograms per kilogram; Std. dev., standard deviation; RSD, relative standard deviation; <, less than]

\begin{tabular}{|c|c|c|c|c|c|c|c|c|c|c|}
\hline \multirow[t]{2}{*}{ Compound } & \multicolumn{7}{|c|}{ Concentration units ( $\mu \mathrm{g} / \mathrm{kg}$ wet weight) } & \multirow[t]{2}{*}{ Mean } & \multirow{2}{*}{$\begin{array}{l}\text { Std. } \\
\text { dev. }\end{array}$} & \multirow{2}{*}{$\begin{array}{c}\text { RSD } \\
\text { (percent) }\end{array}$} \\
\hline & $\mathrm{A}$ & B & $\mathrm{C}$ & $\mathrm{D}$ & $\mathrm{E}$ & $F$ & $\bar{G}$ & & & \\
\hline alpha-HCH & $<5$ & $<5$ & $<5$ & $<5$ & $<5$ & $<5$ & $<5$ & & & \\
\hline Hexachlorobenzene & $<5$ & $<5$ & $<5$ & $<5$ & $<5$ & $<5$ & $<5$ & & & \\
\hline Pentachloroanisole & $<5$ & $<5$ & $<5$ & $<5$ & $<5$ & $<5$ & $<5$ & & & \\
\hline beta-HCH & $<5$ & $<5$ & $<5$ & $<5$ & $<5$ & $<5$ & $<5$ & & & \\
\hline gamma-HCH & $<5$ & $<5$ & $<5$ & $<5$ & $<5$ & $<5$ & $<5$ & & & \\
\hline delta-HCH & $<5$ & $<5$ & $<5$ & $<5$ & $<5$ & $<5$ & $<5$ & & & \\
\hline Heptachlor & $<5$ & $<5$ & $<5$ & $<5$ & $<5$ & $<5$ & $<5$ & & & \\
\hline Aldrin & $<5$ & $<5$ & $<5$ & $<5$ & $<5$ & $<5$ & $<5$ & & & \\
\hline DCPA & $<5$ & $<5$ & $<5$ & $<5$ & $<5$ & $<5$ & $<5$ & & & \\
\hline Heptachlor epoxide & $<5$ & $<5$ & $<5$ & $<5$ & $<5$ & $<5$ & $<5$ & & & \\
\hline Oxychlordane & $<5$ & $<5$ & $<5$ & $<5$ & $<5$ & $<5$ & $<5$ & & & \\
\hline trans-Chlordane & 9.1 & 8.4 & 7.5 & 8.4 & 7.2 & 9.4 & 8 & 8.3 & 0.08 & 9.5 \\
\hline$o, p^{\prime}-\mathrm{DDE}$ & $<5$ & $<5$ & $<5$ & $<5$ & $<5$ & $<5$ & $<5$ & & & \\
\hline cis-Chlordane & 10.4 & 10.5 & 8.8 & 10.6 & 8.5 & 10.6 & 8.2 & 9.7 & 1.1 & 11.4 \\
\hline trans-Nonachlor & 10.3 & 10.2 & 9.6 & 11 & 8.9 & 11.2 & 8.1 & 9.9 & 1.1 & 11.3 \\
\hline Dieldrin & 14.1 & 14 & 12.4 & 13.7 & 10.5 & 14.1 & 10.3 & 12.7 & 1.7 & 13.2 \\
\hline$p, p^{\prime}-\mathrm{DDE}$ & 7.2 & 5.3 & 4.7 & 5 & 3.8 & 4.9 & 5.1 & 5.2 & 1 & 20.1 \\
\hline$o, p^{\prime}-\mathrm{DDD}$ & $<5$ & $<5$ & $<5$ & $<5$ & $<5$ & $<5$ & $<5$ & & & \\
\hline Endrin & $<5$ & $<5$ & $<5$ & $<5$ & $<5$ & $<5$ & $<5$ & & & \\
\hline cis-Nonachlor & $<5$ & $<5$ & $<5$ & $<5$ & $<5$ & $<5$ & $<5$ & & & \\
\hline$p, p^{\prime}-\mathrm{DDD}$ & 9.9 & 9.5 & 9.2 & 10.7 & 7.4 & 10.6 & 8 & 9.3 & 1.2 & 13.4 \\
\hline$o, p^{\prime}-\mathrm{DDT}$ & $<5$ & $<5$ & $<5$ & $<5$ & $<5$ & $<5$ & $<5$ & & & \\
\hline$p, p^{\prime}-\mathrm{DDT}$ & $<5$ & $<5$ & $<5$ & $<5$ & $<5$ & $<5$ & $<5$ & & & \\
\hline$o, p^{\prime}$-Methoxychlor & $<5$ & $<5$ & $<5$ & $<5$ & $<5$ & $<5$ & $<5$ & & & \\
\hline$p, p^{\prime}$-Methoxychlor & $<5$ & $<5$ & $<5$ & $<5$ & $<5$ & $<5$ & $<5$ & & & \\
\hline Mirex & $<5$ & $<5$ & $<5$ & $<5$ & $<5$ & $<5$ & $<5$ & & & \\
\hline Lipid & 2.3 & 2.3 & 2 & 2.2 & 2.1 & 2.4 & 2.1 & 2.2 & 0.1 & 6.4 \\
\hline
\end{tabular}


Table 8. Percent recovery of 5-microgram-per-kilogram spike in homogenized corbicula tissue

[Std. dev., standard deviation; RSD, relative standard deviation; ND, not detected; NR, not reported]

\begin{tabular}{|c|c|c|c|c|c|c|c|c|c|c|}
\hline \multirow[t]{2}{*}{ Compound } & \multicolumn{7}{|c|}{ Recovery of individual compounds, in percent } & \multirow[t]{2}{*}{ Mean } & \multirow{2}{*}{$\begin{array}{l}\text { Std. } \\
\text { dev. }\end{array}$} & \multirow{2}{*}{$\begin{array}{c}\text { RSD } \\
\text { (percent) }\end{array}$} \\
\hline & A. & $\mathrm{B}$ & $\mathrm{C}$ & $\mathrm{D}$ & $\mathrm{E}$ & $\mathrm{F}$ & $\mathrm{G}$ & & & \\
\hline alpha-HCH & 70 & 81 & 72 & 107 & 87 & 85 & 78 & 83 & 12 & 15 \\
\hline Hexachlorobenzene & 72 & 63 & 76 & 90 & 84 & 81 & 82 & 78 & 9 & 11 \\
\hline Pentachloroanisole & 76 & 72 & 85 & 103 & 78 & 91 & 80 & 78 & 9 & 11 \\
\hline beta-HCH & 86 & 80 & 91 & 101 & 93 & 100 & 89 & 91 & 7 & 8 \\
\hline gamma-HCH & 65 & 67 & 87 & 150 & 136 & 131 & 107 & 106 & 34 & 32 \\
\hline delta-HCH & 62 & 31 & 35 & 81 & 76 & 76 & 74 & 62 & 21 & 33 \\
\hline Heptachlor & 71 & 59 & 74 & 84 & 76 & 72 & 70 & 72 & 7 & 10 \\
\hline Aldrin & 65 & 56 & 68 & 83 & 75 & 72 & 73 & 70 & 8 & 12 \\
\hline DCPA & 84 & 93 & 97 & 188 & 230 & 186 & 99 & 140 & 60 & 43 \\
\hline Heptachlor epoxide & ND & ND & ND & ND & ND & ND & ND & & & \\
\hline Oxychlordane & 118 & 108 & 124 & 153 & 139 & 141 & 144 & 132 & 16 & 12 \\
\hline trans-Chlordane & 92 & 79 & 104 & 138 & 132 & 127 & 116 & 113 & 22 & 19 \\
\hline$o, p^{\prime}-\mathrm{DDE}$ & 14 & 14 & 15 & 20 & 26 & 21 & 20 & 19 & 4 & 24 \\
\hline cis-Chlordane & 75 & 56 & 87 & 165 & 133 & 124 & 106 & 107 & 37 & 35 \\
\hline trans-Nonachlor & 115 & 100 & 132 & 182 & 141 & 142 & 42 & 122 & 44 & 36 \\
\hline Dieldrin* & 96 & ND & 119 & 194 & 151 & 158 & 146 & 144 & 34 & 24 \\
\hline$p, p^{\prime}-\mathrm{DDE}$ & 100 & 71 & 102 & 139 & 104 & 99 & 79 & 99 & 22 & 22 \\
\hline$o, p^{\prime}-\mathrm{DDD}$ & 77 & 68 & 64 & 104 & 82 & 95 & 81 & 82 & 14 & 17 \\
\hline Endrin & 36 & 41 & 56 & 83 & 68 & 66 & 65 & 59 & 16 & 28 \\
\hline cis-Nonachlor & 78 & 67 & 83 & 103 & 88 & 87 & 91 & 85 & 11 & 13 \\
\hline$p, p^{\prime}-\mathrm{DDD}$ & NR & NR & NR & NR & NR & NR & NR & & & \\
\hline $0, p^{\prime}-\mathrm{DDT}$ & ND & ND & ND & ND & ND & ND & ND & & & \\
\hline$p, p^{\prime}-\mathrm{DDT}$ & 105 & 77 & 104 & 151 & 123 & 181 & 123 & 123 & 34 & 28 \\
\hline $0, p^{\prime}$-Methoxychlor & 84 & 81 & 72 & 74 & 71 & 74 & 90 & 78 & 7 & 9 \\
\hline$p, p^{\prime}$-Methoxychlor & 95 & 92 & 108 & 113 & 111 & 47 & 48 & 88 & 29 & 33 \\
\hline Mirex & 94 & 66 & 92 & 84 & 80 & 78 & 79 & 82 & 9 & 12 \\
\hline
\end{tabular}

${ }^{*} n=6$, all others $n=7$. 
Table 9. Percent recovery of 40-microgram-per-kilogram spike in homogenized corbicula tissue

[Std. dev., standard deviation; RSD, relative standard deviation; ND, not detected]

\begin{tabular}{|c|c|c|c|c|c|c|c|c|c|c|}
\hline \multirow[t]{2}{*}{ Compound } & \multicolumn{7}{|c|}{ Recovery of individual compounds, in percent } & \multirow[t]{2}{*}{ Mean } & \multirow{2}{*}{$\begin{array}{l}\text { Std. } \\
\text { dev. }\end{array}$} & \multirow{2}{*}{$\begin{array}{c}\text { RSD } \\
\text { (percent) }\end{array}$} \\
\hline & $\mathrm{A}$ & $\mathrm{B}$ & $C$ & $\mathrm{D}$ & $E$ & $F$ & $G$ & & & \\
\hline$\overline{a l p h a-\mathrm{HCH}}$ & $\mathrm{ND}$ & $\mathrm{ND}$ & $\mathrm{ND}$ & $\mathrm{ND}$ & $\overline{\mathrm{ND}}$ & $\mathrm{ND}$ & $\mathrm{ND}$ & & & \\
\hline Hexachlorobenzene & 86 & 90 & 95 & 84 & 89 & 84 & 86 & 88 & 4 & 4 \\
\hline Pentachloroanisole & 79 & 82 & 87 & 78 & 85 & 82 & 83 & 82 & 3 & 4 \\
\hline beta-HCH & 81 & 86 & 91 & 84 & 91 & 84 & 91 & 87 & 4 & 5 \\
\hline gamma-HCH & 59 & 65 & 69 & 60 & 67 & 61 & 69 & 64 & 4 & 7 \\
\hline delta-HCH & 71 & 94 & 95 & 65 & 64 & 65 & 97 & 79 & 16 & 20 \\
\hline Heptachlor & 85 & 76 & 83 & 69 & 74 & 67 & 80 & 76 & 7 & 9 \\
\hline Aldrin & 88 & 77 & 77 & 63 & 64 & 55 & 78 & 72 & 11 & 16 \\
\hline DCPA & 73 & 79 & 85 & 76 & 85 & 78 & 81 & 80 & 4 & 6 \\
\hline Heptachlor epoxide & 88 & 89 & 95 & 82 & 92 & 90 & 89 & 89 & 4 & 4 \\
\hline Oxychlordane & $\mathrm{ND}$ & ND & $\mathrm{ND}$ & ND & $\mathrm{ND}$ & ND & $\mathrm{ND}$ & & & \\
\hline trans-Chlordane & 89 & 90 & 96 & 85 & 95 & 93 & 87 & 91 & 4 & 4 \\
\hline$o, p^{\prime}-\mathrm{DDE}$ & 43 & 40 & 44 & 35 & 38 & 35 & 39 & 39 & 4 & 9 \\
\hline cis-Chlordane & 69 & 72 & 79 & 65 & 74 & 67 & 70 & 71 & 5 & 7 \\
\hline trans-Nonachlor & 81 & 82 & 88 & 76 & 89 & 88 & 85 & 84 & 5 & 6 \\
\hline Dieldrin & 85 & 95 & 103 & 86 & 96 & 88 & 102 & 94 & 7 & 8 \\
\hline$p, p^{\prime}-\mathrm{DDE}$ & 110 & 113 & 110 & 89 & 93 & 84 & 111 & 101 & 12 & 12 \\
\hline$o, p^{\prime}-\mathrm{DDD}$ & 85 & 89 & 94 & 80 & 89 & 85 & 100 & 89 & 7 & 7 \\
\hline Endrin & 106 & 111 & 117 & 115 & 110 & 102 & 113 & 111 & 5 & 5 \\
\hline cis-Nonachlor & 87 & 84 & 100 & 80 & 97 & 100 & 82 & 90 & 9 & 10 \\
\hline$p, p^{\prime}-\mathrm{DDD}$ & 97 & 102 & 106 & 90 & 100 & 87 & 107 & 98 & 8 & 8 \\
\hline$o, p^{\prime}-\mathrm{DDT}$ & 49 & 46 & 51 & 38 & 41 & 38 & 47 & 44 & 5 & 12 \\
\hline$p, p^{\prime}-\mathrm{DDT}$ & 97 & 108 & 113 & 99 & 104 & 98 & 115 & 105 & 7 & 7 \\
\hline$o, p^{\prime}$-Methoxychlor & 147 & 151 & 159 & 134 & 149 & 147 & 155 & 149 & 8 & 5 \\
\hline$p, p^{\prime}$-Methoxychlor & 114 & 116 & 122 & 106 & 118 & 112 & 115 & 115 & 5 & 4 \\
\hline Mirex & 117 & 110 & 114 & 100 & 109 & 112 & 107 & 110 & 5 & 5 \\
\hline
\end{tabular}


Table 10. Percent recovery of 2.5-microgram-per-kilogram reagent spike

[Std. dev., standard deviation; RSD, relative standard deviation; NS, not spiked, standards not available; ND, not detected]

\begin{tabular}{|c|c|c|c|c|c|c|c|c|c|c|}
\hline \multirow[t]{2}{*}{ Compound } & \multicolumn{7}{|c|}{ Recovery of individual compounds, in percent } & \multirow[t]{2}{*}{ Mean } & \multirow{2}{*}{$\begin{array}{l}\text { Std. } \\
\text { dev. }\end{array}$} & \multirow{2}{*}{$\begin{array}{c}\text { RSD } \\
\text { (percent) }\end{array}$} \\
\hline & A & $\mathrm{B}$ & $C$ & $\mathrm{D}$ & $\mathrm{E}$ & $\bar{F}$ & $\mathrm{G}$ & & & \\
\hline alpha-HCH & 48 & 54 & 44 & 49 & 45 & 50 & 44 & 48 & 3 & 7 \\
\hline Hexachlorobenzene & 84 & 77 & 59 & 71 & 67 & 70 & 62 & 70 & 9 & 12 \\
\hline Pentachloroanisole & 71 & 75 & 56 & 69 & 64 & 69 & 67 & 67 & 6 & 9 \\
\hline beta-HCH & 61 & 80 & 73 & 73 & 68 & 75 & 70 & 71 & 6 & 8 \\
\hline gamma-HCH & 69 & 60 & 56 & 55 & 50 & 56 & 52 & 57 & 6 & 11 \\
\hline delta-HCH & 70 & 102 & 96 & 96 & 84 & 95 & 94 & 91 & 11 & 12 \\
\hline Heptachlor & 71 & 67 & 74 & 74 & 59 & 66 & 66 & 68 & 5 & 8 \\
\hline Aldrin & 56 & 56 & 55 & 56 & 50 & 53 & 52 & 54 & 2 & 4 \\
\hline DCPA & 87 & 100 & 92 & 94 & 93 & 100 & 93 & 94 & 5 & 5 \\
\hline Heptachlor epoxide & 122 & 92 & 86 & 88 & 79 & 88 & 89 & 92 & 14 & 15 \\
\hline Oxychlordane & NS & NS & NS & NS & NS & NS & NS & & & \\
\hline trans-Chlordane & 73 & 87 & 83 & 86 & 78 & 88 & 91 & 84 & 6 & 7 \\
\hline$o, p^{\prime}-\mathrm{DDE}$ & NS & NS & NS & NS & NS & NS & NS & & & \\
\hline cis-Chlordane & 68 & 88 & 82 & 82 & 80 & 85 & 84 & 81 & 6 & 8 \\
\hline trans-Nonachlor & 79 & 89 & 83 & 87 & 78 & 89 & 93 & 85 & 6 & 7 \\
\hline Dieldrin & 58 & 77 & 73 & 72 & 59 & 65 & 62 & 67 & 7 & 11 \\
\hline$p, p^{\prime}-\mathrm{DDE}$ & 64 & 64 & 64 & 65 & 62 & 64 & 65 & 64 & 1 & 2 \\
\hline$o, p^{\prime}-\mathrm{DDD}$ & 60 & 74 & 67 & 67 & 65 & 71 & 66 & 67 & 4 & 6 \\
\hline Endrin & 82 & 95 & 92 & 87 & 83 & 93 & 94 & 89 & 5 & 6 \\
\hline cis-Nonachlor & 77 & 92 & 88 & 88 & 83 & 92 & 97 & 88 & 7 & 7 \\
\hline$p, p^{\prime}-\mathrm{DDD}$ & 76 & 73 & 65 & 68 & 73 & 81 & 126 & 80 & 21 & 26 \\
\hline$o, p^{\prime}-\mathrm{DDT}$ & 52 & 77 & 61 & 59 & 56 & 65 & 48 & 60 & 9 & 16 \\
\hline$p, p^{\prime}-\mathrm{DDT}{ }^{*}$ & 67 & 117 & 109 & 85 & 82 & 93 & ND & 92 & 18 & 20 \\
\hline$o, p^{\prime}$-Methoxychlor & 165 & 182 & 164 & 156 & 162 & 174 & 148 & 164 & 11 & 7 \\
\hline$p, p^{\prime}$-Methoxychlor & 216 & 241 & 238 & 196 & 203 & 217 & 184 & 214 & 21 & 10 \\
\hline Mirex & 107 & 115 & 115 & 117 & 107 & 115 & 122 & 114 & 5 & 5 \\
\hline
\end{tabular}

${ }^{*} n=6$. 
Table 11. Percent recovery of 40-microgram-per-kilogram reagent spike

[Std. dev., standard deviation; RSD, relative standard deviation]

\begin{tabular}{|c|c|c|c|c|c|c|c|c|}
\hline \multirow[t]{2}{*}{ Compound } & \multicolumn{5}{|c|}{ Recovery of individual compounds, in percent } & \multirow[t]{2}{*}{ Mean } & \multirow{2}{*}{$\begin{array}{l}\text { Std. } \\
\text { dev. }\end{array}$} & \multirow{2}{*}{$\begin{array}{c}\text { RSD } \\
\text { (percent) }\end{array}$} \\
\hline & $\mathrm{A}$ & $\mathrm{B}$ & $\mathrm{C}$ & $\mathrm{D}$ & $\mathrm{E}$ & & & \\
\hline alpha-HCH & 86 & 82 & 79 & 87 & 84 & 84 & 3 & 4 \\
\hline Hexachlorobenzene & 110 & 116 & 95 & 111 & 108 & 108 & 8 & 7 \\
\hline Pentachloroanisole & 88 & 91 & 86 & 92 & 89 & 89 & 2 & 3 \\
\hline beta-HCH & 94 & 88 & 85 & 92 & 90 & 90 & 4 & 4 \\
\hline gamma-HCH & 91 & 80 & 89 & 77 & 84 & 84 & 6 & 7 \\
\hline delta-HCH & 97 & 90 & 107 & 92 & 97 & 97 & 7 & 7 \\
\hline Heptachlor & 84 & 81 & 92 & 67 & 81 & 81 & 9 & 11 \\
\hline Aldrin & 89 & 87 & 99 & 67 & 86 & 86 & 12 & 14 \\
\hline DCPA & 94 & 84 & 95 & 85 & 89 & 89 & 5 & 6 \\
\hline Heptachlor epoxide & 98 & 86 & 95 & 63 & 86 & 86 & 14 & 16 \\
\hline Oxychlordane & 93 & 84 & 83 & 81 & 85 & 85 & 5 & 5 \\
\hline trans-Chlordane & 94 & 89 & 99 & 81 & 91 & 91 & 6 & 7 \\
\hline$o, p^{\prime}-\mathrm{DDE}$ & 57 & 50 & 60 & 37 & 51 & 51 & 9 & 18 \\
\hline cis-Chlordane & 94 & 89 & 97 & 81 & 90 & 90 & 6 & 7 \\
\hline trans-Nonachlor & 89 & 85 & 92 & 80 & 87 & 87 & 5 & 5 \\
\hline Dieldrin & 92 & 88 & 99 & 91 & 93 & 93 & 4 & 4 \\
\hline$p, p^{\prime}-\mathrm{DDE}$ & 90 & 100 & 103 & 79 & 93 & 93 & 9 & 10 \\
\hline$o, p^{\prime}-\mathrm{DDD}$ & 88 & 83 & 89 & 91 & 88 & 88 & 3 & 3 \\
\hline Endrin & 93 & 89 & 95 & 81 & 90 & 90 & 5 & 6 \\
\hline cis-Nonachlor & 95 & 90 & 102 & 81 & 92 & 92 & 8 & 8 \\
\hline$p, p^{\prime}-\mathrm{DDD}$ & 84 & 88 & 98 & 92 & 90 & 90 & 5 & 6 \\
\hline $0, p^{\prime}-\mathrm{DDT}$ & 64 & 74 & 70 & 67 & 69 & 69 & 4 & 5 \\
\hline$p, p^{\prime}-\mathrm{DDT}$ & 108 & 110 & 111 & 81 & 102 & 102 & 13 & 12 \\
\hline$o, p^{\prime}$-Methoxychlor & 87 & 90 & 92 & 68 & 84 & 84 & 9 & 11 \\
\hline$p, p^{\prime}$-Methoxychlor & 112 & 115 & 107 & 83 & 104 & 104 & 12 & 12 \\
\hline Mirex & 94 & 94 & 106 & 74 & 92 & 92 & 11 & 12 \\
\hline
\end{tabular}


Table 12. Percent recovery from National Institute of Standards and Technology Standard Reference Material 1588 cod liver oil

[Std. dev., standard deviation; RSD, relative standard deviation]

\begin{tabular}{|c|c|c|c|c|c|c|c|c|c|c|}
\hline \multirow[t]{2}{*}{ Compound } & \multicolumn{7}{|c|}{ Recovery of individual compounds, in percent } & \multirow[t]{2}{*}{ Mean } & \multirow{2}{*}{$\begin{array}{l}\text { Std. } \\
\text { dev. }\end{array}$} & \multirow{2}{*}{$\begin{array}{c}\text { RSD } \\
\text { (percent }\end{array}$} \\
\hline & $\mathrm{A}$ & $\mathrm{B}$ & C & $\mathrm{D}$ & $E$ & $\mathrm{~F}$ & $\mathrm{G}$ & & & \\
\hline Hexachlorobenzene & 106 & 90 & 105 & 96 & 98 & 109 & 96 & 100 & 7 & 7 \\
\hline alpha-HCH & 52 & 47 & 50 & 42 & 51 & 55 & 48 & 49 & 4 & 9 \\
\hline trans-Chlordane & 180 & 166 & 115 & 104 & 109 & 122 & 119 & 131 & 30 & 23 \\
\hline cis-Chlordane & 109 & 99 & 98 & 92 & 99 & 113 & 90 & 100 & 8 & 8 \\
\hline trans-Nonachlor & 101 & 94 & 102 & 96 & 101 & 105 & 103 & 100 & 4 & 4 \\
\hline Dieldrin & 73 & 70 & 76 & 70 & 81 & 71 & 74 & 74 & 4 & 5 \\
\hline$p, p^{\prime}-\mathrm{DDD}$ & 135 & 115 & 109 & 42 & 139 & 185 & 162 & 127 & 46 & 36 \\
\hline$p, p^{\prime}-\mathrm{DDE}$ & 88 & 73 & 83 & 72 & 69 & 90 & 79 & 79 & 8 & 11 \\
\hline$o, p^{\prime}-\mathrm{DDT}$ & 93 & 85 & 96 & 82 & 51 & 69 & 84 & 80 & 15 & 19 \\
\hline$p, p^{\prime}-\mathrm{DDT}$ & 81 & 77 & 97 & 65 & 74 & 84 & 79 & 80 & 10 & 12 \\
\hline
\end{tabular}


Table 13a. Results of U.S. Fish and Wildlife round-robin sample 2

[Concentration units in micrograms per kilogram wet weight; NWQL, National Water Quality Laboratory; ${ }^{*}$, abbreviations of other laboratories that participated in the round-robin study; Std. dev., standard deviation; RSD, relative standard deviation]

\begin{tabular}{|c|c|c|c|c|c|c|c|c|c|c|c|c|c|}
\hline Compound & NWQL1 & NWQL2 & MSCL ${ }^{*}$ & GERG1* & GERG2* & MAZL1* & MAZL2* & PACF1* & PACF2* & PACF3 $^{*}$ & Mean & $\begin{array}{l}\text { Std. } \\
\text { dev. }\end{array}$ & $\begin{array}{c}\text { RSD } \\
\text { (percent) }\end{array}$ \\
\hline alpha-HCH & 48 & 53 & 97 & 130 & 124 & 5 & 114 & 100 & 80 & 100 & 85 & 39 & 46 \\
\hline Hexachlorobenzene & 90 & 51 & 65 & 40 & 91 & 100 & 97 & 72 & 60 & 79 & 75 & 20 & 27 \\
\hline gamma-HCH & 68 & 66 & 93 & 110 & 124 & 15 & 85 & 96 & 78 & 97 & 83 & 30 & 36 \\
\hline Heptachlor epoxide & 70 & 56 & 86 & 80 & 101 & 77 & 69 & 80 & 64 & 83 & 77 & 13 & 16 \\
\hline Oxychlordane & 84 & 68 & 88 & 90 & 106 & 89 & 64 & 83 & 64 & 84 & 82 & 13 & 16 \\
\hline trans-Chlordane & 89 & 74 & 85 & 110 & 126 & 96 & 103 & 92 & 77 & 94 & 95 & 15 & 16 \\
\hline$o, p^{\prime}-\mathrm{DDE}$ & 81 & 81 & 80 & 100 & 115 & 75 & 99 & 44 & 56 & 85 & 82 & 21 & 25 \\
\hline cis-Chlordane & 104 & 84 & 79 & 100 & 115 & 87 & 80 & 83 & 68 & 82 & 88 & 14 & 16 \\
\hline trans-Nonachlor & 102 & 84 & 100 & 100 & 125 & 100 & 151 & 91 & 78 & 94 & 103 & 21 & 21 \\
\hline Dieldrin & 101 & 84 & 90 & 120 & 97 & 100 & 118 & 85 & 80 & 93 & 97 & 14 & 14 \\
\hline$p, p^{\prime}-\mathrm{DDE}$ & 168 & 130 & 110 & 170 & 125 & 140 & 133 & 190 & 110 & 110 & 139 & 28 & 20 \\
\hline$o, p^{\prime}-\mathrm{DDD}$ & 120 & 84 & 120 & 40 & 106 & 99 & 110 & 100 & 78 & 100 & 96 & 24 & 25 \\
\hline Endrin & 110 & 94 & 97 & 90 & 104 & 110 & 89 & 88 & 83 & 96 & 96 & 9 & 10 \\
\hline$p, p^{\prime}-\mathrm{DDD}$ & 120 & 99 & 120 & 160 & 122 & 90 & 127 & 110 & 86 & 110 & 114 & 21 & 19 \\
\hline$o, p^{\prime}-\mathrm{DDT}$ & 110 & 92 & 120 & 160 & 124 & 83 & 115 & 130 & 97 & 130 & 116 & 22 & 19 \\
\hline$p, p^{\prime}$-DDT & 120 & 100 & 98 & 140 & 116 & 100 & 159 & 140 & 110 & 140 & 122 & 21 & 17 \\
\hline Mirex & 87 & 83 & 90 & 120 & 100 & 96 & 111 & 69 & 62 & 67 & 89 & 19 & 22 \\
\hline Total PCB & 450 & 350 & 370 & 520 & 672 & 390 & 480 & 580 & 590 & 530 & 493 & 105 & 21 \\
\hline Toxaphene & 400 & 320 & 490 & 25 & 246 & 290 & 530 & 560 & 490 & 590 & 394 & 176 & 45 \\
\hline Lipid, in percent & 3.3 & 3.5 & 2.4 & 2.9 & 3.2 & 3.5 & 14.6 & 2.0 & 1.7 & 1.6 & 3.9 & 3.8 & 99.7 \\
\hline
\end{tabular}


Table 13b. Results of U.S. Fish and Wildlife round-robin sample 12

[Concentration units in micrograms per kilogram wet weight; NWQL, National Water Quality Laboratory; ${ }^{*}$, abbreviations of other laboratories that participated in the round-robin study; Std. dev., standard deviation; RSD, relative standard deviation]

\begin{tabular}{|c|c|c|c|c|c|c|c|c|c|c|c|c|c|}
\hline Compound & NWQL1 & NWQL2 & $\mathrm{MSCL}^{*}$ & GERG1* & GERG2* & MAZL1* $^{*}$ & MAZL2* & PACF1* & $\mathrm{PACF}^{*}$ & PACF3* $^{*}$ & Mean & $\begin{array}{l}\text { Std. } \\
\text { dev. }\end{array}$ & $\begin{array}{c}\text { RSD } \\
\text { (percent) }\end{array}$ \\
\hline alpha-HCH & 45 & 75 & 97 & 130 & 129 & 15 & 132 & 85 & 96 & 87 & 89 & 38 & 42 \\
\hline Hexachlorobenzene & 51 & 47 & 65 & 40 & 127 & 111 & 70 & 75 & 72 & 73 & 73 & 27. & 37 \\
\hline gamma-HCH & 62 & 68 & 93 & 100 & 128 & 32 & 87 & 84 & 91 & 77 & 82 & 25 & 31 \\
\hline Heptachlor epoxide & 66 & 76 & 86 & 90 & 111 & 73 & 72 & 70 & 86 & 75 & 81 & 13 & 16 \\
\hline Oxychlordane & 78 & 88 & 87 & 100 & 106 & 88 & 66 & 71 & 80 & 84 & 85 & 12 & 14 \\
\hline trans-Chlordane & 84 & 98 & 87 & 110 & 129 & 94 & 115 & 79 & 88 & 88 & 97 & 16 & 16 \\
\hline$o, p^{\prime}-\mathrm{DDE}$ & 76 & 85 & 82 & 110 & 111 & 76 & 107 & 44 & 56 & 85 & 83 & 22 & 27 \\
\hline cis-Chlordane & 100 & 110 & 81 & 100 & 119 & 85 & 77 & 69 & 78 & 78 & 90 & 16 & 18 \\
\hline trans-Nonachlor & 98 & 110 & 100 & 110 & 128 & 110 & 157 & 79 & 89 & 97 & 108 & 22 & 20 \\
\hline Dieldrin & 100 & 62 & 93 & 120 & 98 & 98 & 138 & 85 & 91 & 61 & 95 & 23 & 25 \\
\hline$p, p^{\prime}-\mathrm{DDE}$ & 130 & 130 & 110 & 160 & 126 & 140 & 122 & 100 & 110 & 100 & 123 & 19 & 15 \\
\hline$o, p^{\prime}-\mathrm{DDD}$ & 91 & 120 & 120 & 30 & 107 & 99 & 113 & 91 & 100 & 97 & 97 & 26 & 27 \\
\hline Endrin & 110 & 128 & 100 & 90 & 105 & 110 & 89 & 90 & 97 & 69 & 99 & 16 & 16 \\
\hline$p, p^{\prime}-\mathrm{DDD}$ & 110 & 130 & 130 & 160 & 126 & 110 & 128 & 94 & 100 & 100 & 119 & 20 & 17 \\
\hline$o, p^{\prime}$-DDT & 110 & 120 & 130 & 160 & 125 & 88 & 119 & 110 & 120 & 130 & 121 & 18 & 15 \\
\hline$p, p^{\prime}-\mathrm{DDT}$ & 110 & 130 & 130 & 150 & 123 & 110 & 151 & 120 & 120 & 150 & 129 & 16 & 12 \\
\hline Mirex & 82 & 89 & 91 & 120 & 102 & 110 & 103 & 76 & 75 & 72 & 92 & 16 & 18 \\
\hline Total PCB & 350 & 310 & 360 & 530 & 725 & 400 & 440 & 500 & 530 & 520 & 467 & 122 & 26 \\
\hline Toxaphene & 370 & 420 & 550 & 25 & 267 & 270 & 460 & 490 & 550 & 600 & 400 & 174 & 44 \\
\hline Lipid, in percent & 3.4 & 3.5 & 2.4 & 1.2 & 7.6 & 3.6 & 13.5 & 2.1 & 1.9 & 1.7 & 4.1 & 3.8 & 92.3 \\
\hline
\end{tabular}


Table 14. Results of U.S. Environmental Protection Agency quality-control samples

$[\mu \mathrm{g} / \mathrm{kg}$, micrograms per kilogram; Std. dev., standard deviation; RSD, relative standard deviation]

\begin{tabular}{|c|c|c|c|c|c|c|c|c|}
\hline \multirow[t]{2}{*}{ Compound } & \multirow{2}{*}{$\begin{array}{c}\text { Accepted } \\
\text { value }\end{array}$} & \multicolumn{4}{|c|}{$\begin{array}{l}\text { Concentration units } \\
(\mu \mathrm{g} / \mathrm{kg} \text { wet weight })\end{array}$} & \multirow[t]{2}{*}{ Mean } & \multirow{2}{*}{$\begin{array}{l}\text { Std. } \\
\text { dev. }\end{array}$} & \multirow{2}{*}{$\begin{array}{c}\text { RSD } \\
\text { (percent }\end{array}$} \\
\hline & & $\overline{\mathrm{A}}$ & $\mathrm{B}$ & $\mathrm{C}$ & $\mathrm{D}$ & & & \\
\hline cis-Chlordane & 20 & 17 & 16 & 17 & $\overline{18}$ & 17 & 0.8 & 4.8 \\
\hline trans-Chlordane & 17 & 12 & 14 & 15 & 15 & 14 & 1.4 & 10 \\
\hline cis-Nonachlor & 9 & 11 & 10 & 11 & 11 & 11 & .5 & 4.7 \\
\hline trans-Nonachlor & 28 & 22 & 21 & 23 & 22 & 22 & .8 & 3.7 \\
\hline Oxychlordane & 3 & 3 & 4 & 3 & 3 & 3 & .2 & 7.4 \\
\hline Total chlordane & 78 & 65 & 65 & 69 & 69 & 67 & 2.6 & 3.9 \\
\hline Acceptable range & $60-96$ & & & & & & & \\
\hline$p, p^{\prime}-\mathrm{DDD}$ & 8 & 11 & 12 & 12 & 12 & 12 & .5 & 4.3 \\
\hline$p, p^{\prime}-\mathrm{DDE}$ & 44 & 45 & 42 & 46 & 45 & 45 & 1.7 & 3.9 \\
\hline$p, p^{\prime}-\mathrm{DDT}$ & 0 & 0 & 0 & 0 & 0 & 0 & 0 & \\
\hline Total DDX & 52 & 56 & 54 & 58 & 57 & 56 & 1.7 & 3.0 \\
\hline Acceptable range & $32-72$ & & & & & & & \\
\hline Lipid, in percent & 3 & 6 & 4 & 5 & 4 & 5 & 1 & 20 \\
\hline Acceptable range & $2-4$ & & & & & & & \\
\hline
\end{tabular}


Table 15. Method detection limits determined with reagent spike

[Std. dev., standard deviation; RSD, relative standard deviation; $n$, number of replicates; $\mu \mathrm{g} / \mathrm{kg}$, micrograms per kilogram; MDL, method detection limit; ND, not determined]

\begin{tabular}{|c|c|c|c|c|c|c|c|}
\hline Compound & $\begin{array}{c}\text { Mean } \\
\text { concentration } \\
(\mu \mathrm{g} / \mathrm{kg})\end{array}$ & $\begin{array}{c}\text { Std. dev. } \\
(\mu \mathrm{g} / \mathrm{kg})\end{array}$ & $\begin{array}{c}\text { RSD } \\
\text { (percent) }\end{array}$ & $n$ & $\begin{array}{l}\text { Amount } \\
\text { spiked } \\
(\mu \mathrm{g} / \mathrm{kg}) \\
\end{array}$ & $t$-value & $\begin{array}{c}\text { MDL } \\
(\mu \mathrm{g} / \mathrm{kg})\end{array}$ \\
\hline alpha-HCH & 1.19 & 0.09 & 7.18 & 7 & 2.5 & 3.1427 & 0.3 \\
\hline Hexachlorobenzene & 1.75 & .21 & 12.2 & 7 & 2.5 & 3.1427 & .7 \\
\hline Pentachloroanisole & 1.68 & .15 & 8.95 & 7 & 2.5 & 3.1427 & .5 \\
\hline beta-HCH & 1.78 & .15 & 8.20 & 7 & 2.5 & 3.1427 & .5 \\
\hline gamma-HCH & 1.42 & .15 & 10.8 & 7 & 2.5 & 3.1427 & .5 \\
\hline delta-HCH & 2.28 & .26 & 11.6 & 7 & 2.5 & 3.1427 & .8 \\
\hline Heptachlor & 1.70 & .13 & 7.81 & 7 & 2.5 & 3.1427 & .4 \\
\hline Aldrin & 1.35 & .05 & 3.99 & 7 & 2.5 & 3.1427 & .2 \\
\hline DCPA & 2.35 & .11 & 4.88 & 7 & 2.5 & 3.1427 & .4 \\
\hline Heptachlor epoxide & 2.30 & .35 & 15.2 & 7 & 2.5 & 3.1427 & 1.1 \\
\hline Oxychlordane & ND & & & 7 & 2.5 & 3.1427 & ND \\
\hline trans-Chlordane & 2.09 & .16 & 7.48 & 7 & 2.5 & 3.1427 & .5 \\
\hline$o, p^{\prime}-\mathrm{DDE}$ & ND & & & 7 & 2.5 & 3.1427 & ND \\
\hline cis-Chlordane & 2.03 & .16 & 7.64 & 7 & 2.5 & 3.1427 & .5 \\
\hline trans-Nonachlor & 2.14 & .14 & 6.55 & 7 & 2.5 & 3.1427 & .4 \\
\hline Dieldrin & 1.67 & .19 & 11.2 & 7 & 2.5 & 3.1427 & .6 \\
\hline$p, p^{\prime}-\mathrm{DDE}$ & 1.60 & .02 & 1.56 & 7 & 2.5 & 3.1427 & ND \\
\hline$o, p^{\prime}-\mathrm{DDD}$ & 1.68 & .11 & 6.30 & 7 & 2.5 & 3.1427 & .3 \\
\hline Endrin & 2.24 & .13 & 6.02 & 7 & 2.5 & 3.1427 & .4 \\
\hline cis-Nonachlor & 2.20 & .16 & 7.45 & 7 & 2.5 & 3.1427 & .5 \\
\hline$p, p^{\prime}-\mathrm{DDD}$ & 2.01 & .52 & 25.9 & 7 & 2.5 & 3.1427 & 1.6 \\
\hline$o, p^{\prime}-\mathrm{DDT}$ & 1.49 & .24 & 15.9 & 7 & 2.5 & 3.1427 & .7 \\
\hline$p, p^{\prime}-\mathrm{DDT}$ & 1.98 & .97 & 49 & 7 & 2.5 & 3.1427 & 3.0 \\
\hline$o, p^{\prime}$-Methoxychlor & 4.11 & .28 & 6.79 & 7 & 2.5 & 3.1427 & .9 \\
\hline$p, p^{\prime}$-Methoxychlor & 5.34 & .53 & 9.86 & 7 & 2.5 & 3.1427 & 1.7 \\
\hline Mirex & 2.85 & .13 & 4.72 & 7 & 2.5 & 3.1427 & .4 \\
\hline
\end{tabular}


Table 16. Method detection limits determined with homogenized fish tissue

[Std. dev., standard deviation; RSD, relacive standard deviation; $n$, number of replicates; $\mu \mathrm{g} / \mathrm{kg}$, micrograms per kilogram; MDL, method detection limit]

\begin{tabular}{|c|c|c|c|c|c|c|c|}
\hline Compound & $\begin{array}{c}\text { Mean } \\
\text { concentration } \\
(\mu \mathrm{g} / \mathrm{kg})\end{array}$ & $\begin{array}{l}\text { Std. dev. } \\
(\mu \mathrm{g} / \mathrm{kg})\end{array}$ & $\begin{array}{c}\text { RSD } \\
\text { (percent) }\end{array}$ & $n$ & $\begin{array}{l}\text { Amount } \\
\text { spiked } \\
(\mu \mathrm{g} / \mathrm{kg}) \\
\end{array}$ & $t$-value & $\begin{array}{c}\text { MDL } \\
(\mu \mathrm{g} / \mathrm{kg})\end{array}$ \\
\hline alpha-HCH & 2.13 & 0.1 & 4.87 & 7 & 2.0 & 3.1427 & 0.31 \\
\hline Hexachlorobenzene & 1.79 & .23 & 13.1 & 7 & 2.0 & 3.1427 & .74 \\
\hline Pentachloroanisole & 2.11 & .25 & 12 & 7 & 2.0 & 3.1427 & .76 \\
\hline beta-HCH & 2.15 & .42 & 19.6 & 7 & 2.0 & 3.1427 & 1.26 \\
\hline gamma-HCH & 2.06 & .28 & 13.7 & 7 & 2.0 & 3.1427 & .85 \\
\hline delta-HCH & 1.95 & .19 & 9.5 & 7 & 2.0 & 3.1427 & .56 \\
\hline Heptachlor & 1.59 & .18 & 11.2 & 7 & 2.0 & 3.1427 & .56 \\
\hline Aldrin & 1.73 & .15 & 8.65 & 7 & 2.0 & 3.1427 & .47 \\
\hline DCPA & 1.75 & .17 & 9.66 & 7 & 2.0 & 3.1427 & .51 \\
\hline Heptachlor epoxide & 2.01 & .22 & 10.8 & 7 & 2.0 & 3.1427 & .66 \\
\hline Oxychlordane & 2.05 & .48 & 23.5 & 7 & 2.0 & 3.1427 & 1.44 \\
\hline trans-Chlordane & 1.94 & .29 & 15.1 & 7 & 2.0 & 3.1427 & .88 \\
\hline$o, p^{\prime}-\mathrm{DDE}$ & 1.8 & .36 & 20.1 & 7 & 2.0 & 3.1427 & 1.09 \\
\hline cis-Chlordane & 2.35 & .24 & 10.4 & 7 & 2.0 & 3.1427 & .73 \\
\hline trans-Nonachlor & 2.18 & .16 & 7.27 & 7 & 2.0 & 3.1427 & .47 \\
\hline Dieldrin & 2.18 & .31 & 14.1 & 7 & 2.0 & 3.1427 & .92 \\
\hline$p, p^{\prime}-\mathrm{DDE}$ & 2.06 & .32 & 15.6 & 7 & 2.0 & 3.1427 & 1.01 \\
\hline$o, p^{\prime}-\mathrm{DDD}$ & 2.08 & .22 & 10.5 & 7 & 2.0 & 3.1427 & .66 \\
\hline Endrin & 2.1 & .2 & 9.52 & 7 & 2.0 & 3.1427 & .6 \\
\hline cis-Nonachlor & 1.9 & .32 & 16.6 & 7 & 2.0 & 3.1427 & .95 \\
\hline$p, p^{\prime}-\mathrm{DDD}$ & 2.09 & .35 & 16.7 & 7 & 2.0 & 3.1427 & 1.04 \\
\hline$o, p^{\prime}-\mathrm{DDT}$ & 2.23 & .29 & 12.9 & 7 & 2.0 & 3.1427 & .86 \\
\hline$p, p^{\prime}-\mathrm{DDT}$ & 2.38 & .22 & 9.21 & 7 & 2.0 & 3.1427 & .66 \\
\hline$o, p^{\prime}$-Methoxychlor & 1.81 & .22 & 12 & 7 & 2.0 & 3.1427 & .66 \\
\hline$p, p^{\prime}$-Methoxychlor & 1.83 & .18 & 9.6 & 7 & 2.0 & 3.1427 & .53 \\
\hline Mirex & 1.96 & .37 & 19.1 & 7 & 2.0 & 3.1427 & 1.17 \\
\hline
\end{tabular}

